\title{
Attepe Bölgesindeki Siderit Olușumlarının Mineralojik Özellikleri ve Jeotektonik Ortamı (Kayseri-Adana Havzası, Türkiye)
}

\section{Geotectonic Setting and Mineralogical Properties of Siderite Occurences in Attepe Region (Kayseri-Adana Basin, Turkey)}

\author{
SERDAR KESKIN ${ }^{1 *}$, TANER ÜNLÜ² \\ ${ }^{1}$ MTA Doğu Karadeniz Bölge Müdürlüğü, 61010, Trabzon \\ ${ }^{2}$ Ankara Üniversitesi, Mühendislik Fakültesi, Jeoloji Mühendisliği Bölümü, 06100, Ankara
}

\author{
Geliș (received) : : 01 Șubat (February) 2016 \\ Kabul (accepted) : : 04 Ağustos (August) 2016
}

\section{öz}

Bu çalıșma, Doğu Toroslar'ın batısında yer alan Attepe ve civarındaki demir yataklarından alınan siderit olușumlarının mineralojik özelliklerini, $\delta^{13} \mathrm{C}$ ve $\delta^{18} \mathrm{O}$ izotopik bileșimlerini ve olușum ortamları hakkındaki öncel verileri kapsamaktadır. Kayseri-Adana Havzası'nda yer alan demir cevherleșmeleri genellikle (1) Prekambriyen yașlı birim içinde sedimanter pirit ve siderit, (2) Alt Kambriyen yașlı kuvarsit ile Orta-Üst Kambriyen yașlı kireçtașları arasında hidrotermal-dolgu tipi, (3) Orta-Üst Kambriyen yașlı kireçtașları içinde hidrotermal-metazomatik hematit, siderit, ankerit ve süperjen götit-limonit, (4) Ordovisiyen yașlı kalkșist mercekleri ile șeyller içerisinde hidrotermal siderit ve hematit ve (5) Jura-Kretase yașlı metakonglomeralar içerisinde breșik cevherler olarak görülmektedir. Birincil cevher, Prekambriyen yașlı Emirgazi Formasyonu içerisindeki bitümlü metapelitik kayaçlar ile uyumlu sinsedimanter siderit $\left(\mathrm{FeCO}_{3}\right)$ cevherleșmeleridir. Günümüzde ișletilen hidrotermal-metazomatik ve hidrotermal-dolgu tipi hematit, siderit, götit ve limonit cevher olușumları geç evre ve superjen demir yataklarını olușturmaktadır. Cevherleșmenin kökenini ortaya koymak için Prekambriyen yașlı sideritler ile hidrotermal sideritlerde karbon ve oksijen izotop çalıșmaları ile SEM-EDS gibi mikroskobik çalıșmalar yürütülmüștür. Birincil sideritlerdeki $\delta^{13} \mathrm{C}$ değerleri \%o-0.71 ile \%o-1.62 arasında, $\delta^{18} \mathrm{O}$ değerleri \%o-9.95 ile \%o-10.68 arasındadır. Buna karșın ikincil olușumlu sideritlerdeki $\delta^{13} \mathrm{C}$ değerleri \%o-6.57 ile \%о-7.94 arasında, $\delta^{18} \mathrm{O}$ değerleri de \%o-10.29 ile \%o-12.03 arasındadır. Siderit örneklerinden elde edilen $\delta^{13} \mathrm{C}$ ve $\delta^{18} \mathrm{O}$ izotop sonuçlarına göre; birincil kökenli demir cevherleșmeleri, diyajenetik veya sin-sedimanter demir olușumlarını, ikincil kökenli geç evre demir cevherleșmeleri ise demirce zengin hidrotermal-metazomatik kökeni ve Mn-Mg siderit cevherleșmelerini göstermektedir. Hidrotermal kökenli geç evre demir cevherleșmeleri, birincil cevherleșme sonrası KD-GB doğrultulu fay zonlarında dolașan demirce zengin hidrotermal eriyiklerin, Orta-Üst Kambriyen yașlı kireçtașları ile etkileșimi neticesinde olușmuștur. Birincil siderit cevherleșmelerinin bulunduğu Prekambriyen yașlı Emirgazi Formasyonu, KB Gondwana'nın İnfra-Kambriyen yașlı kayaç birimlerini temsil etmekte ve Gondwana'nın en kuzeyinde riftle-ilișkili kayaç birimleriyle benzer özellik göstermektedir.

Anahtar Kelimeler: Attepe, duraylı izotop, Emirgazi Formasyonu, Prekambriyen, siderit.

\section{ABSTRACT}

This study includes prior data that are $\delta^{13} \mathrm{C}$ and $\delta^{18} \mathrm{O}$ isotopic features, mineralogical features and depositional setting of siderite occurences taken from iron deposits in Attepe and its surrounding area, located on the western part of Eastern Taurus. The iron mineralization in Kayseri-Adana Basin can be usually observed as sedimentary pyrite and siderite in Precambrian aged outcrops (1), hydrothermal-fill type between Lower Cambrian aged quartzite and Middle-Late Cambrian aged limestones (2), hydrothermal-metasomatic hematite, siderite, ankerite and supergene goethite-limonite in Middle-Late Cambrian aged limestones (3), hydrothermal siderite and hematite in Ordavician aged shale and calcschist lens (4), breccia ores in Jura-Cretaceous aged metaconglomerates (5). Primary ore is the syn-sedimentary siderite $\left(\mathrm{FeCO}_{3}\right)$ mineralization conformable with bitumen-shale in Precambrian aged Emirgazi Formation. Hydrothermal-metasomatic and hydrothermal-fill type hematite, siderite, goethite and limonite ore mineralization are the late stage and supergene iron deposits which are being mined today. It has been carried out such as $C$ and $O$ isotope studies and SEM-EDS microscopic studies from Precambrian aged siderites and hydrothermal siderites

\footnotetext{
*S.Keskin

e-posta: serdar.keskin@mta.gov.tr
} 
for reveal to origin of mineralizations. The $\delta^{13} \mathrm{C}$ values of primary siderites range from $-0.71 \%$ to $-1.62 \%$, and of the $\delta^{18} \mathrm{O}$ values between $-9.95 \%$ and $-10.68 \%$. On the other hand the $\delta^{13} \mathrm{C}$ values of secondary siderites range from $-6.57 \%$ o to $-7.94 \%$, and of the $\delta^{18} \mathrm{O}$ values between $-10.29 \%$ and $-12.03 \%$. According to $\delta^{18} \mathrm{O}$ and $\delta^{13} \mathrm{C}$ isotope results obtained from siderite samples; the primary mineralizations are the diagenetic or syn-sedimentary iron formations and, late-stages of secondary iron mineralizations also show the iron-rich hydrothermal-metasomatic origin and $\mathrm{Mn}-\mathrm{Mg}$ siderite mineralizations. Hydrothermal origin of late stage iron mineralizations are products of interaction between Midde-Late Cambrian limestones and iron-rich hydrothermal fluids circulating throughout the fault zones after primary mineralization at deep. Precambrian aged Emirgazi Formation including primary siderite mineralizations, represents Infra-Cambrian aged rock units of NW Gondwana and shows similar characteristics to the rift-related rock units in the northernmost of Gondwana.

Keywords: Attepe, stable isotope, Emirgazi Formation, Precambrian, siderite.

\section{GiRiș}

Doğu Akdeniz bölgesinde bulunan Türkiye, jeolojik geçmiși boyunca kuzeyde Lavrasya ve güneyde Gondwana'yı içeren büyük kıtasal levhalar arasında yer almıștır. Bu nedenle Türkiye pek çok Alpin ve Alpin öncesi tektonik birlik içerir. Miyosen'de Afrika ve Anadolu plakalarının çarpıșmasıyla ilişkili deformasyon yapıları ve çarpıșma sonrası kıta içi tektonik-kaçma ile Kuzey Anadolu Fayı, Doğu Anadolu Fayı ve Anadolu mikrolevhası olușmuștur (Dewey vd., 1986; Burke ve Şengör, 1986; Koçyiğit ve Bayhan, 1998). Anadolu plakacığının doğu kısmında kalan inceleme alanında (Şekil 1) bir dizi aktif, kıta içi, sağ ve sol yönlü doğrultu altımlı faylar (Tuz Gölü Fayı, Göksu-Yazıyurdu Fay Zonu, Malatya-Ovacık Fay Zonu, Orta Anadolu Fay Zonu) ve bunlarla ilișkili çek ayır havzalar baskındır (Koçyiğit ve Bayhan, 1998; Bozkurt, 2001; Koç ve Kaymakçı, 2013). İnceleme alanının, Türkiye'deki Alpin tektonik birliklerden biri olan Toridler'in (Özgül, 1984) Doğu Toroslar bölümünde, Orta Anadolu Fay Zonu (Ecemiș Koridoru) ile Göksu-Yazıyurdu Fay Zonu arasında yer alıyor olması (Koçyiğit ve Deveci, 2007), bölgede yer alan demir yataklarının tektonizmadan da etkilendiğini göstermektedir.

Bu çalıșmaya konu olan ve Doğu Toroslar'ın batısında Kayseri-Adana bölgesinde yer alan Attepe ve civarındaki demir yatakları ile ilgili çeșitli araștırmalar (Küpeli, 1986; Ünlü ve Stendall,1986; Dağlıoğlu ve Bahçeci, 1999; Dağlıoğlu ve Arda, 2000; Küpeli, 1991; Dayan, 2007; Küpeli vd., 2007; Arda vd., 2008; Tiringa vd., 2009; Küpeli, 2010) yapılmıș olmasına rağmen, demir yataklarının geniș ölçekte olușum ortamı konusunda ve tektonizma ile olan ilișkisi hakkında detaylı çalıșmalar henüz yapılmamıștır. Çalıșma alanının temelinde Prekambriyen yașlı Emirgazi Formasyonu'na ait volkanik istiflerin bulunması ve bu kayaçlarla ilișkili sin-sedimanter (birincil) siderit cevherleșmelerinin varlığı, Toros Kușağı'nın Pan-Afrikan Orojenezi ile olan ilișkisini anlatmakta önem tașımaktadır.

Jeolojik evrim olarak bakıldığında Gondwana'nın bütünleșmesiyle ilgili olayları kapsayan Pan-Afrikan Orojenezi'nin 950-450 M.y. arasındaki bir süreci içerdiği kabul görmektedir (Kröner ve Stern, 2005). Geç Proterozoyik dönemdeki kıta dağılımları, Doğu ve Batı Gondwana'nın Mozambik Okyanusu adı verilen bir okyanusla birbirinden ayrıldığını göstermektedir. Gondwana'nın En Geç Proterozoyik'teki final bir araya gelme evresinde, Toroslar'ın Mozambik Kușağı'nın en kuzey kesiminde, Afrika-Arap Yarımadası'nın kuzeydoğusunda yer aldığı düșünülmektedir (Stern, 1994; Wilson vd., 1997; Gürsu vd., 2015; Gürsu, 2016). Günümüzde Alpin orojenik kușağının içinde yer alan ve Gondwana/Peri-Gondwana kabuk parçaları olarak tanımlanan bu birimlerin Geç Proterozoyik temelleri gibi Erken Paleozoyik örtüleri de büyük çapta benzerlik göstermektedir (Önalan, 1986; Dean ve Monod, 1997; Demirel ve Kozlu, 1997; Cocks, 2000). $\mathrm{Bu}$ benzerliklere dayanılarak, paleotektonik modellerde çalıșma alanının da içinde bulunduğu Toroslar, Peri-Gondwvana olarak tanımlanan Gondwana kıtasının, kuzey kenarına yerleștirilmiștir (Göncüoğlu, 1997; Gürsu ve Göncüoğlu, 2005; Ghienne vd., 2010; Göncüoğlu ve Kozlu, 2000). Bu çalıșma bağlamında, öncel çalıșmalar da dikkate alınarak bölgede Prekambriyen yașlı volkanik ve sedimanter kayaçların, çalışma alanındaki birincil siderit cevherleșmeleri ile olan arazi bulgularının ortaya konulması istenmektedir.

Ayrıca Prekambriyen yașlı birimler içindeki birincil siderit yataklarından türemiș olan ve günümüzde ișletilmekte olan ikincil demir yataklarının (özellikle; hematit ve siderit), geç evre hidrotermal cevher damarlarının ve süperjen ve karst koșullarında zenginleșmiș olan götit ve limonit cevherleșmelerin faylanmalarla olan ilișkisi de bu makalede ele alınmıștır. 


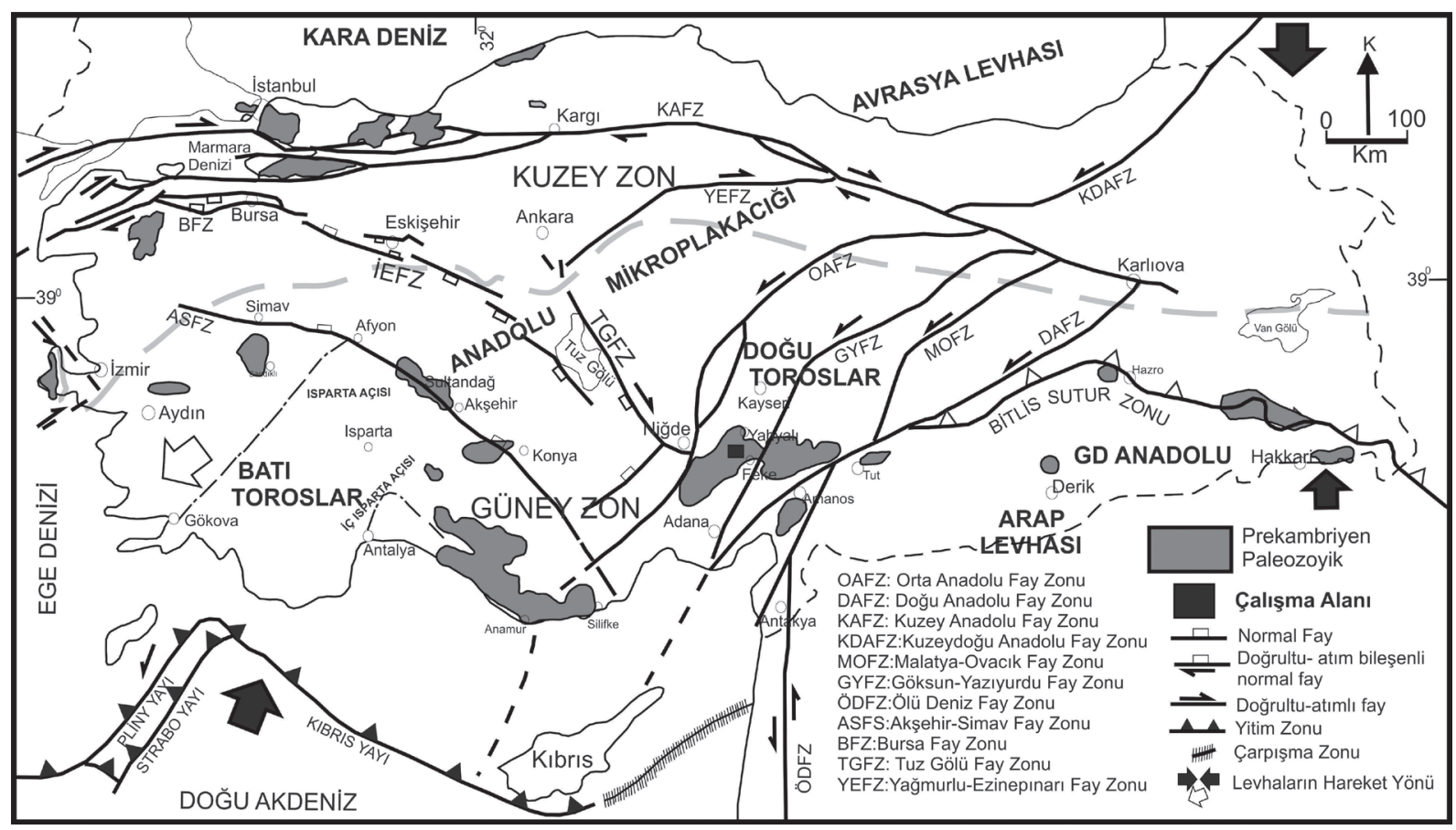

Şekil 1. Türkiye ve civarındaki ana fay zonları, Prekambriyen-Paleozoyik birimler ve çalıșma alanının bu birimler içindeki yeri (Prekambriyen-Paleozoyik birimler ve faylar Dean ve Monod, 1997; Göncüoğlu ve Kozlu, 2000; Koçyiğit ve Deveci, 2007'den derlenmiștir).

Figure 1. The main fault zones of Turkey and its surroundings, Precambrian-Paleozoic outcrops, and study area in these units (Precambrian-Paleozoic outcrops and faults compiled from Dean and Monod, 1997; Göncüoğlu and Kozlu, 2000; Koçyiğit and Deveci, 2007).

\section{YÖNTEM}

Çalışma, Attepe demir yatağı ve çevresindeki; Karaçat, Kartalkaya, Menteș, Karakızoluğu ve Uyuzpınarı demir (hematit, siderit, götit, limonit) yatak ve zuhurlarının haritalanması, kıvrımlanma ve tektonizma ile olan ilișkisi ile maden jeolojisini içermektedir. Özellikle Attepe, Karaçat ve Kartalkaya demir yataklarının olușumuyla ilișkili düşünülen faylar, cevher yataklarının oluşumunda yapı kontrolüne örnek gösterilebilecek özellikte yapılar olarak değerlendirilmiștir. FaultKinWin 6.0 (Allmendinger, 2013) programına girilen değerlerle bu fayları etkileyen asal gerilim eksenlerinin konumları ortaya çıkarılmıștır. Ayrıca Prekambriyen içindeki metapelitik kayaçlarla uyumlu birincil siderit $\left(\mathrm{FeCO}_{3}\right)$ cevherleșmeleri ile geç evre ikincil siderit cevherleșmelerinden alınan örneklerde Arizona Üniversitesi laboratuvarlarında duraylı izotop (karbon ve oksijen izotopları) çalıșmaları yürütülmüștür. Cevher örneklerin Maden Tetkik ve Arama Genel Müdürlüğü (MTA) ve Ankara Üniversitesi laboratuvarlarında taramalı elektron mikroskobu (SEM-EDS) ve cevher mikroskopisi çalıșmaları yapılarak cevher- leșmenin kökeni hakkında yorumlamaya gidilmiș ve cevherin olușumu sırasındaki jeotektonik ortam modelleri üzerinde durulmuștur.

\section{BÖLGESEL JEOLOJi}

Doğu Toroslar'ın batı kesiminde, Orta Anadolu Fay Zonu (OAFZ) Göksu-Yazıyurdu Fay Zonu (GYFZ) arasında yer alan çalıșma alanı ve yakın çevresi (Șekil 1) farklı stratigrafik özellikleri, aralarında belirgin ayrımlar bulunan, birbirleriyle tektonik dokanaklı değișik tektono-stratigrafik birlikleri kapsar. Çalıșma alanı günümüze değin bir çok araștırmacı tarafından incelenmiș olup, çeșitli șekillerde alt birliklere ayrılmıştır (Brunn vd., 1971; Özgül, 1971, 1976, 1984; Tekeli, 1980; Tutkun, 1984; Metin vd., 1986; Bedi ve Usta, 2006; Ghienne vd., 2010). Birlikler yüzeylemelerinin yaygın olduğu yüksek dağlar ya da yerleșim yerlerinin adlarıyla; Geyik Dağı Birliği, Aladağ Birliği, Bolkar Dağı Birliği, Bozkır Birliği, Alanya Birliği ve Antalya Birliği olarak (Şekil 2A) adlandırılmıștır (Özgül, 1976). Çalıșma alanını olușturan ve bölgede geniș alanlar 
kaplayan Geyikdağı Birliği, Prekambriyen-Tersiyer aralığının tüm çökel sistemlerini kontrol eden bașlıca șelf tipi karbonat ve kırıntılı kayaları kapsar. Geyikdağı Birliği inceleme alanının batısında Bozkır birlikleri tarafından tektonik olarak üstlenmiștir (Özgül, 1976; Mackintosh ve Robertson, 2009). Özellikle Lütesiyen sonrası devinimlerle kendi içinde de önemli ölçüde dilimlenmiș ve kendi içlerinde, düșük açılı bindirmelerle önemli ölçüde ekaylanmıșlardır (Özgül ve Kozlu, 2002; Șenel vd., 2004).

Yukarıdaki bilgilerin ıșığında çalıșma alanında gözlenen ana litostratigrafik birimler, Geyikdağı Birliğine ait Prekambriyen yașlı Emirgazi Formasyonu, Alt Kambriyen yașlı Zabuk Formasyonu, Orta-Üst Kambriyen yașlı Değirmentaș Formasyonu, Ordovisiyen yașlı Armutlu Formasyonu, Jura-Kretase yașlı Kızlarsekisi Formasyonu, Bozkır Birliği'ne ait Üst Kretase yașlı Ofiyolitik Melanj ve Miyosen yașlı Yaylacık Formasyonu'ndan olușmaktadır (Özgül vd., 1973) (Șekil 2B ve Șekil 3).

Geyikdağı Tektonik Birliği'ne ait olan bu formasyonlardan Prekambriyen yașlı kayaçlar genellikle bitümlü metapelitik kayaçlar, fillat, șist, sleyt ve bunlarla uyumlu sin-sedimanter sideritler, pirit saçınımları, kıtasal ve sığ denizel klastik kayaçlar ile bazik volkanik kayaçlardan olușmaktadır (Şekil 4A, 4B)

Alt Kambriyen yașlı Zabuk Formasyonu, Emirgazi Formasyonu üzerine uyumsuz olarak gelen, genellikle masif, yer yer çok kalın tabakalı, demirli, orta-iri taneli kuvarsitlerden olușmaktadır (Șekil 4A, 4C). Bu formasyonun taban kesimleri kumtașı ve kuvarsvake türü litolojilerden olușmaktadır (Şenel vd., 2004; Şenel ve Sönmez, 2006). Orta-Üst Kambriyen yașlı Değirmentaș Formasyonu'na ait kireçtașları, kimyasal sedimantasyon yoluyla olușmuș cevher olușumlarının yanı sıra (Tiringa vd., 2009; Eken, 2012) aynı zamanda sahada ekonomik olarak ișletilen hidrotermal-metazomatik kökenli damar tipi demir olușumlarını da barındırmaktadır (Şekil 4D). Ordovisiyen yașlı Armutludere Formasyonu ise fillit-șist, metasilttașı, meta kumtașından olușmakta ve tabanında nodüler kireçtașı-kalkșist birimlerini (Șekil 4D) içermektedir.

İnceleme alanının kuzeybatısında yer alan Jura-Kretase yașlı Kızlarsekisi Formasyonu, kristalize kireçtaşı ve metakonglomera türü kayaçları içermektedir (Şekil 4E). Bu bölgedeki detay jeolojik açıklamalar ve tektono-stratigrafik gelișim Tekeli (1980) ve Özgül ve Kozlu (2002) tarafından verilmiștir.

Çalışma alanında Bozkır Birliği'ne ait olan ofiyolitik kayaçlar dünit, gabro ve serpantinleșmiș peridotit türü kayaçlardır (Şekil 4F). Üst Kretase zamanında Neotetis Okyanus'unun kapanması ile bu kayaçlar temel metamorfik kayaçlar üzerine yerleșmiștir (Tekeli vd., 1984; Robertson vd., 2009). Çalıșma alanında Miyosen yașlı sığ denizel ve karasal konglomeralar, marnlar ve bazaltik-andezitik volkanik kayaçlar ile onların piroklastik ürünleri ile ara seviyeli olan sedimanter örtü tüm istifleri açısal uyumsuzlukla örtmektedir. Yukarıda bahsedilen Geyikdağı Birliği içindeki formasyonların tümü Alpin ve öncesi orojenik olaylardan etkilenmiș olup çok düșük dereceli (yeșilșist fasiyesi) metamorfizma geçirmișlerdir (Özgül vd., 1973).

\section{ATTEPE VE ÇEVRESI DEMIR YATAKLARININ JEOLOJISI VE YAPISAL ÖZELLIKLERI}

Attepe ve civarındaki Karaçat, Elmadağbeli, Mağarabeli, Kartalkaya, Menteș ve Karakızoluğu demir yatakları (siderit, hematit, götit ve limonit) batıda Orta Anadolu Fay Zonu, doğuda ise Doğu Anadolu Fayı ile sınırlandırılan ve bu faylara paralellik gösteren doğrultu atımlı faylarla kesilmiștir. İnceleme alanının yakın çevresinde yapılan çalıșmalarda bölgede Kretase'ye kadar duraylı bir havzaya özgü ortamdan bahsedilmektedir. (Demirel ve Kozlu, 1997; Yılmaz, 2004). Kretase'de Neotetis'in kuzey kolunun kuzeye dalması ile bölgede Kretase öncesi var olan gerilmeli tektonik rejim, yerini sıkıșmalı tektonik rejime bırakmıştır. Üst Kretase'de okyanus kabuğu malzemeleri güney yönde sürüklenmiștir (Andrew ve Robertson, 2002). Böylece kitasal kabukta nap hareketleri de bașlamıștır. Doğu Toroslarda, Erken Eosen'de Geyikdağı Birliği üzerine gelen ofiyolit üzerlemesi gerçekleşmiş ve Lütesiyen sonunda bu üzerleme tamamlanmıștır (Șekil 2A). Geç Eosen'de ise, Toros Karbonat Platformu'nun kuzeyinde yer alan ve Toridler ile Anatolidler'i birbirinden ayıran İç Toros Okyanusu kuzeye dalımını tamamlamıș ve kapanım gerçekleșmiștir. Bu kapanma ile birlikte bölgedeki naplar güney yönünde ekaylanmıșlardır (Şengör vd.,1984; Mackintosh ve Robertson, 2009; Robertson vd., 2009; Akbayram vd., 2013). Geç Kretase sonrası gelișen bu nap hareketleri, birimler arasındaki faylı dokanakları oluşturmuş ve Miyosen'de genișlemeli tektonik rejimin ürünü olan doğrultu atımlı faylar bu nap ürünü bindirme faylarını kesmiștir. Bu sıkıșmalı rejimin ürünleri olan kırılgan deformasyon ürünü bindirme fay zonları ile genișlemeli rejimin ürünleri olan normal faylar inceleme alanında önemli demir cevherleșmelerinin de bulunduğu yerlerdir (Șekil 5A-5L).

$\mathrm{Bu}$ yataklardan Attepe demir yatağındaki cevher, kıvrılma, faylanma ve litolojik kontrollerin etkisiyle 


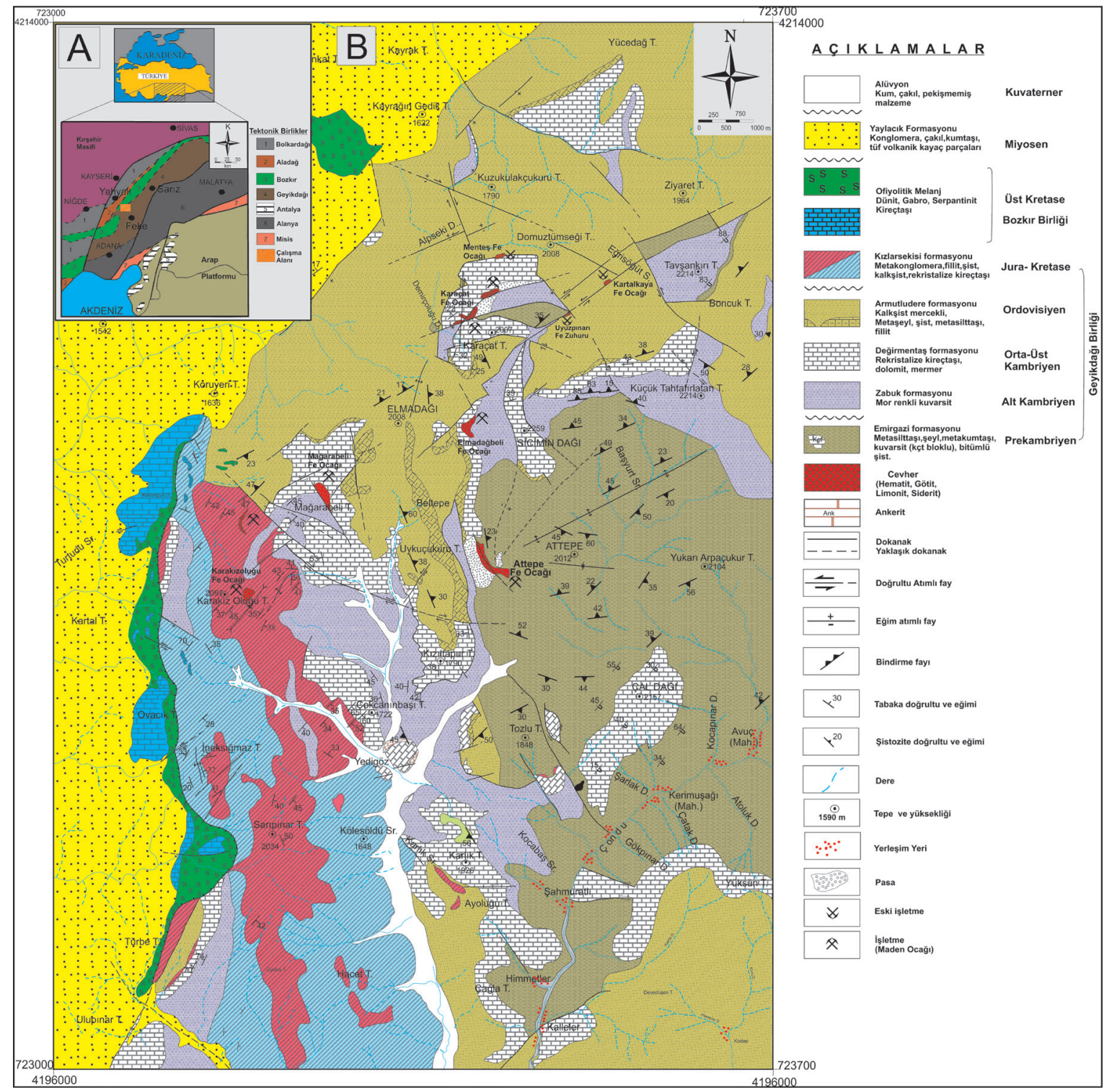

Șekil 2. A) İnceleme alanının Doğu Toroslar'ın tektono-stratigrafik birlikleri içindeki yeri (Özgül, 1976'dan alınmıștır) ve B) Çalıșma alanının jeoloji haritası (Arazi çalıșmaları, Arıkan, 1968; Arda vd., 2009; Akça, 2011'den derlenerek).

Figure 2. A) The location of study area in tectono-stratigraphic units of the Eastern Taurides (taken by Özgül, 1976) and B) Geological map of the study area (Compiled from field studies, Arıkan, 1968; Arda et al., 2009; Akça, 2011).

meydana gelen bir ortamda yerleșmiștir. Kireçtașları ve kumtașlarının kırılgan olușları nedeniyle kıvrılmaları sırasında faylanmalar çok etkin olmuștur. Yatakta birincil siderit cevherlerinden dönüșen hematit cevherleri yaygındır. Hematitler ve sideritler bozușarak götit ve limonite dönüșmüștür. KD-GB yönlü faylar eriyikleri yüzeye ulaștırmıștır (Henden vd., 1978). Prekambriyen birimler içinde yer alan Attepe demir yatağında Attepe Fayı KB-GD doğrultusunda, $48^{\circ}-51^{\circ}$ arasında güneybatıya eğimli normal fay karakterindedir ve 4.5 km uzunluğuna sahiptir (Şekil 5B). Bu faya bağlı birincil sideritlerden dönüșen hematit ve karstik boșluklarda zenginleșmiș götit cevherleșmeleri olup bunlar günümüzde işletilmektedir. Hematit-götit cevherleșmelerine eșlik eden ve cevherleșmeyle eș yașlı Attepe Fayı, sağ ve sol yönlü (KB-GD doğrultulu ve $77^{\circ}-80^{\circ}$ arasında kuzeydoğuya eğimli, yan yatım açıları $13^{\circ}-19^{\circ}$ ile güneye eğimli) doğrultu atımlı faylar 


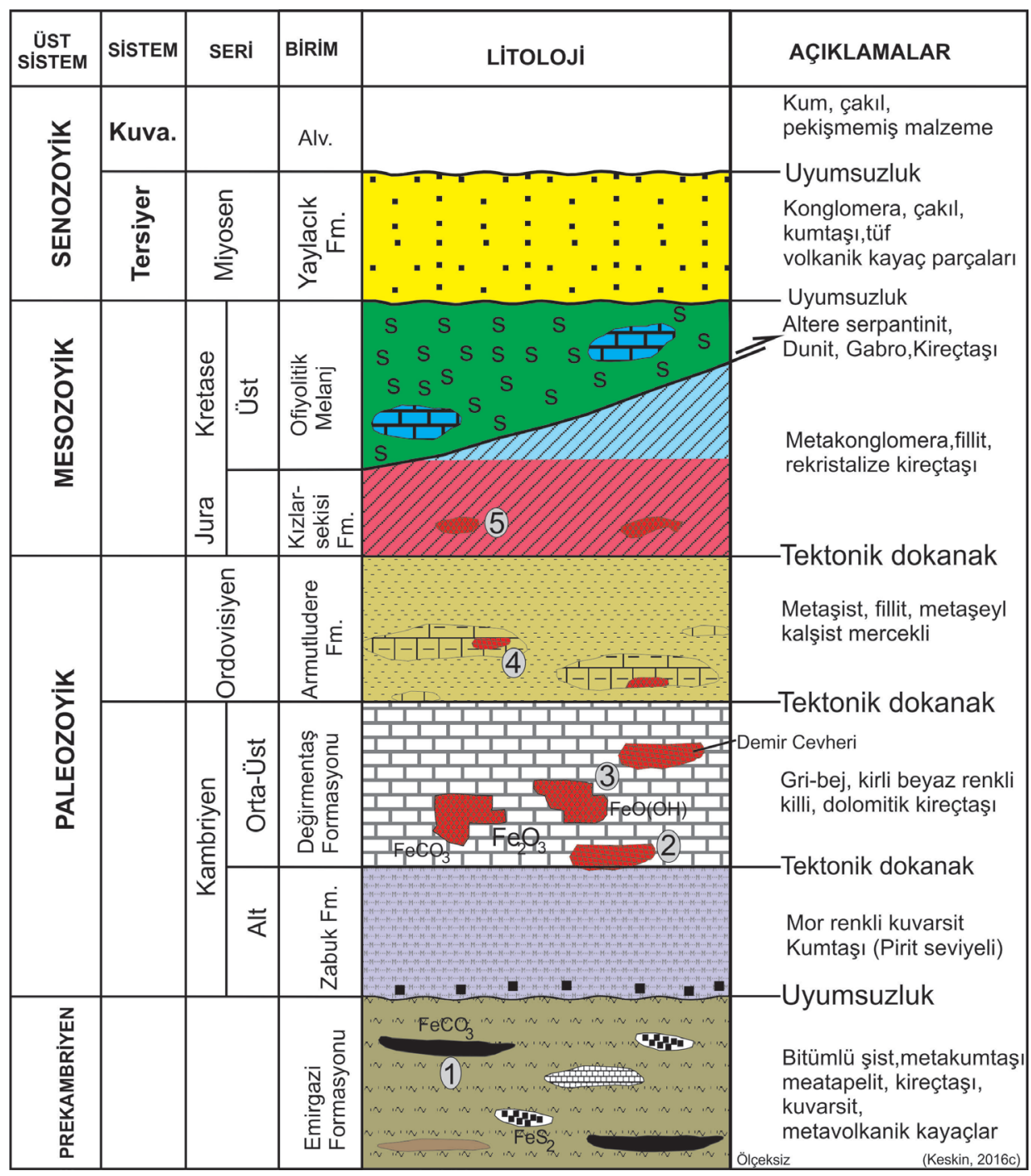

Șekil 3. Çalıșma alanının genelleștirilmiș stratigrafik kolon kesiti ve demir yataklarının (1,2,3,4 ve 5) bu formasyonlar içindeki dağılımı (Șenel vd., 2004'ten değiștirilerek alınmıștır).

Figure 3. Generalized stratigraphic columnar section of the study area and the distrubition of iron deposits (1,2,3,4 and 5) in these formations (Modified after Șenel vd., 2004).

tarafından kesilmektedir (Șekil 5C, 5D). Attepe Fayı boyunca meydana gelen fay breșlerinin cevherleșmiș olması, fayın cevherleșme ile eș zamanlı oluștuğunu göstermektedir. Attepe yatağında MTA tarafından yapılan çalısmalarla \% $58.44 \mathrm{Fe}$ tenörlü 36 milyon ton rezerv bulunmuștur (Henden vd., 1978; Dağlıŏlu, 1990). Ana cevher zonu KKB-GGD doğrultuda olup yaklașık 800-900 metre uzunluktadır.

Çalışma alanındaki bir diğer yatak olan Kartalkaya demir madeni götit ve limoniten oluşmakta ve KDGB doğrultulu ve $65^{\circ}$ ile güneydoğuya eğimli bir sol yönlü doğrultu atımlı fay tarafından atıma uğratıımıștır (Şekil 5E, 5F). Fay düzlemi üzerinde ölçülen fay çiziklerinin yan yatım açısı (rake) $5^{\circ}$ doğuya doğrudur.
Yaklașık 4 km uzunluğunda olan bu cevherleșme sonrası doğrultu atımlı fay zonu KD-GB doğrultusunda uzanmaktadır. Alt Kambriyen yașlı kuvarsit ile Orta-Üst Kambriyen yașlı kireçtașları arasındaki dokanağı olușturan bu faylanma sonucu cevher kesilmiș, atıma uğramıș ve yeniden ișlenerek zenginleșmiștir. Fay zonu boyunca cevherleșmeyle görülen barit minerallerinde yapılan sıvı kapanım çalıșmaları (Keskin vd., 2010b), Kartalkaya Fayı'nın sığ derinlikte bir fay olduğunu göstermektedir. Bu fay zonu boyunca meydana gelen antitetik-sintetik faylanmalar sonucu Uyuzpınarı limonit cevherleșmesi gibi irili ufaklı demir zuhurları da olușmuștur (Șekil 5E, 5G). Bu limonit zuhuru Kartalkaya Fayı'nın uzantısı olan KB- 

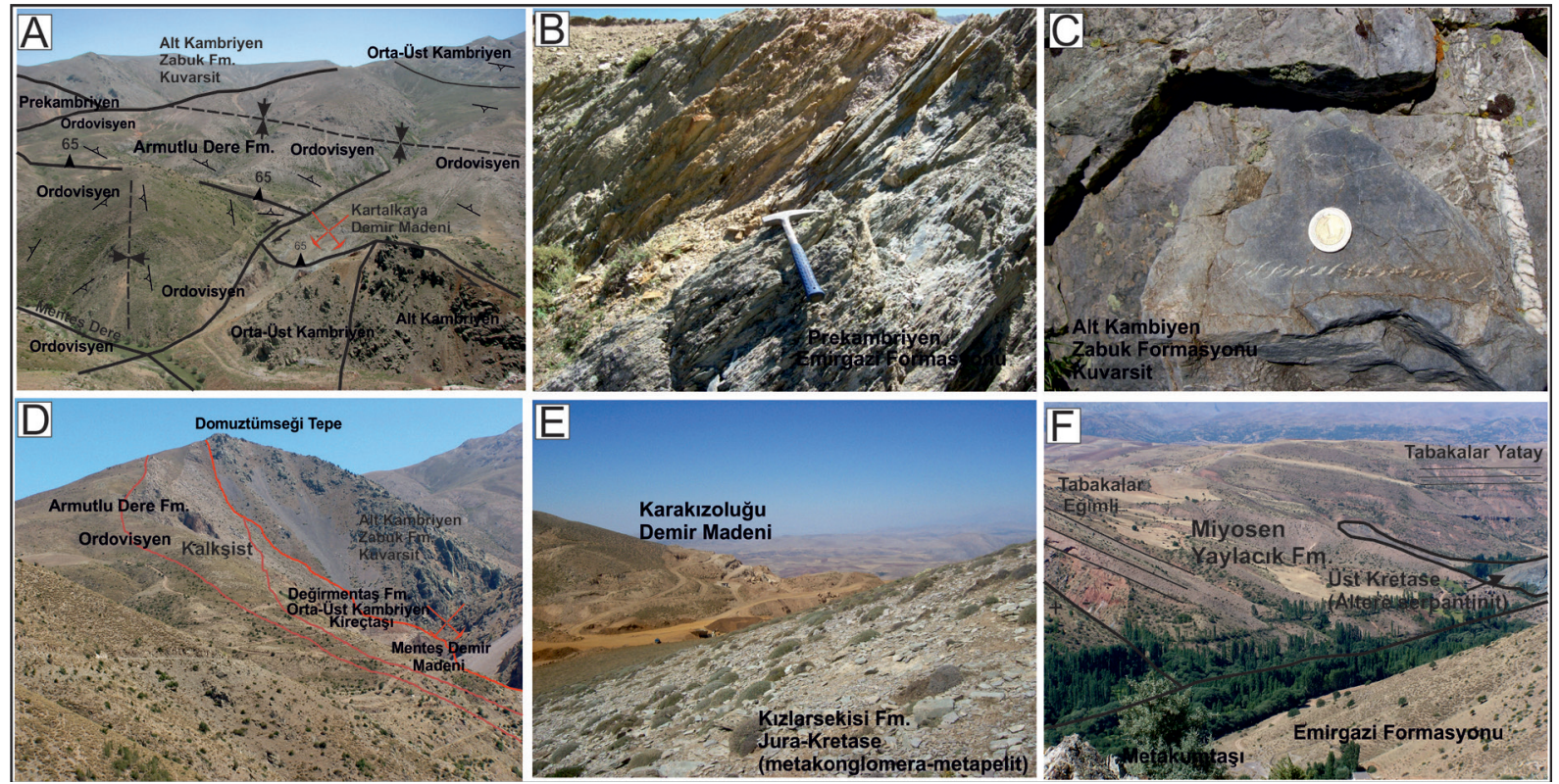

Șekil 4. İnceleme alanının arazi gözlemlerine ait görüntüler. A) Formasyonlar arasındaki dokanaklar ve yapısal unsurlar, B) Prekambriyen yașlı Emirgazi Formasyonu'nun metapelitik kayaçları, C) Alt Kambiyen yașlı Zabuk Formasyonu'nun kuvarsit kayaları üzerinde sol yönlü makaslama zonunu gösteren sigmoidal damarların görünümü, D) Menteș demir madeni etrafındaki formasyonlar, E) Karakızoluğu demir yatağını içeren Jura-Kretase yașlı birimler. F) Prekambriyen yașlı birimler üzerine bindirme ile gelen Üst Kretase yașı serpantinize peridotit kayaçlar ve her ikisi üzerine değișik açılarla gelen Miyosen yașlı Yaylacık Formasyonu.

Figure 4. Field observations images of the study area. A) The boundary between formations and brittle structures, B) Meta-pelitic rocks of Precambrian aged Emirgazi Formation, C) The sigmoidal veins on the quartzite of the Lower Cambrian aged Zabuk Formation that shows left-lateral shearing zone, D) Formations around Menteș iron deposit, E) Jura-Cretaceous outcrops including Karakızoluğu iron deposit, F) Upper Cretaeous aged serpantinized peridotites overthrust to Precambrian aged outcrops, and both of them overlied by different angles outcrops of Miocene aged Yaylacık Formation.

GD doğrultulu ve $60^{\circ}$ ile güneybatıya eğimli sol yönlü bir sintetik doğrultu atımlı fay düzlemine bağlı olarak gelișmiștir. Fayın tavan bloğunda ise 5-6 m kalınlıkta kataklastik zon olușumu görülmektedir. Düzleme yakın kısımlarda yeșilimsi-sarımsı-kırmızımsı-grimsi renkli fay kili olușumu gözlenirken, daha uzak kesimde breșik olușum görülmektedir.

Bölgedeki en önemli yataklardan biri olan Karaçat hematit yatağı içindeki Karaçat Fayı, 2.5 km uzunluğuna sahip olup ters fay niteliğindedir (Şekil 5J). Şu anda ișletilmekte olan bu yataktaki hematit, götit cevherleri (Şekil 5l), cevherleșme sonrası ters fay dokanağında bulunmaktadır. Karaçat demir yatağı içindeki KD-GB doğrultulu ve $55^{\circ}$ ile güneydoğuya eğimli bu ters fay zonundaki cevherleșmiș breșlerin bulunması, cevherin fay breșlerinin içine yerleștiğini göstermektedir. Yani, ilk olarak ters fay yüzeyine birincil hematit cevherleșmesi yerleșmiș, devam eden sıkıșmalı (Șekil 5L) deformasyon (ile olușan yeni fay breșleri), zondaki mevcut cevheri de etkilediğinden dolayı, cevher parçacıklarını fay breșinin içine almıștır. Bu özellik, fayın cevherleșme sonrası (postmineralised) ters fayı olduğunun en önemli kanıtlarından birisidir. (Şekil 5J). Bu ters fay birçok doğrultu atımlı ve eğim atımlı faylar tarafından kesilmektedir (Şekil 5H, 5J, 5K). Karaçat demir yatağındaki cevher gövdesi K70D doğrultulu ve $55-60^{\circ}$ arasında değișen açılarla güneydoğuya eğimli olup 80-100 metre arasında değișen kalınlık ve 600 metre uzunluk sunmaktadır. Hematit cevheri Orta-Üst Kambriyen yașı kreçtașları içerisinde bu faylanmaya bağlı olarak hidrotermal-metazomatik olarak yerleșmiștir. Cevher gövdesinin kalınlığı fay zonunun kalınlığı ile doğru orantılıdır. Karaçat Demir Yatağı'nda yoğun șekilde ikincil kökenli (geç evre) siderit damarları da izlenir (Șekil 5l). Cevhere kuvars ve az da olsa barit gibi gang mineralleri de eşlik eder. Şu anda özel bir sektöre ait yapılan sondajlı aramalar sonucu ișleti- 

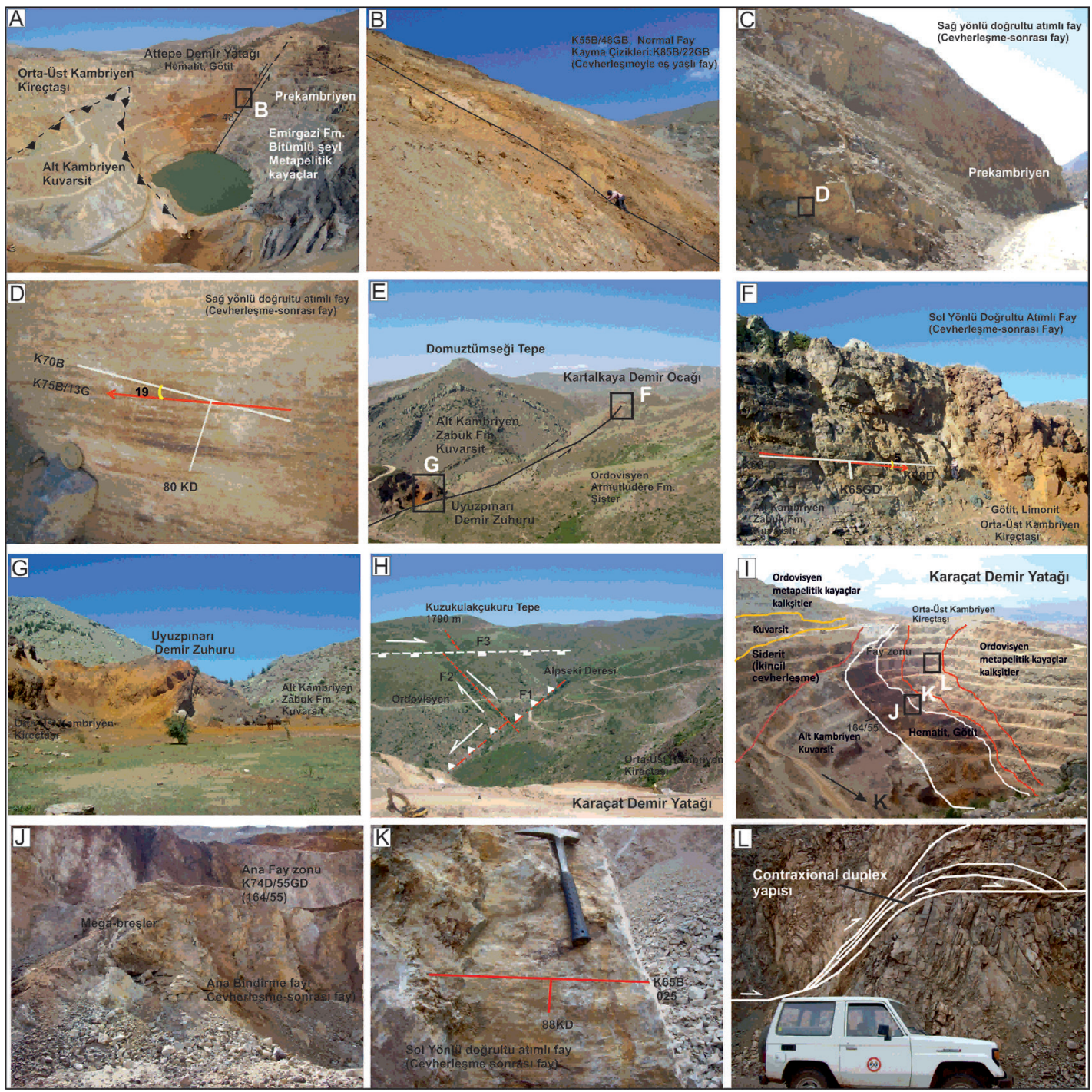

Șekil 5. Attepe, Karaçat ve Kartalkaya maden yataklarının yapısal özellikleri. A) Attepe demir yatağı, B) Attepe demir yatağında cevherleșmeyi olușturan cevherleșmeyle eș yașlı normal fay, C), D) Sektörün güney kesiminde kireçtașlarını kesen cevherleșme sonrası doğrultu atımlı fay, E), F) Kartalkaya demir yatağı içinden geçen cevherleșme-sonrası sol yönlü doğrultu atımlı fay, G) Sintetik doğrultu atımlı fay tarafından kontrol edilen Uyuzpınarı limonit cevherleșmesi, H) Karaçat demir yatağının kuzeyindeki bazı fayların birbiriyle olan ilișkileri. F1 fayı sol yanal bileșenli ters fay özelliğinde olup sondaj çalıșmalarında 190 m.'de kesilmiștir. F2 fayı sağ yönlü doğrultu atımlı fay ve bu fayı kesen F3 fayı da sağ yanal bileșenli normal fay özelliğindedir, I) Karaçat madeni, litolojisi ve cevherin günümüzdeki konumu, J) Karaçat demir yatağı içindeki ana bindirme fay zonundaki cevherleșmiș breșler, K) Yatak içinde hematit cevherini kesen genç doğrultu atımlı faylar, L) Karaçat madeninin batı sektöründe sıkıșmalı rejim sonucu olușan sıkıșmalı dubleks yapıları.

Figure 5. Structural features of Attepe, Karaçat and Kartalkaya iron mines. A) Attepe iron deposit, B) Syn-mineralized normal fault formed to mineralization in Attepe iron deposit, C), D) Post-mineralized strike-slip faults cut the limestones in the south section of iron deposits, E), F) Post-mineralised left-lateral strike-slip fault passes through the Kartalkaya iron deposit, G) The synthetic strike-slip fault controlled to Uyuzpınarı limonite mineralization, $H$ ) The relationships between some faults sytstem in the northern part of Karaçat iron mine. F1 is the thrust fault with sinistral strike-slip component explored by drilling at $190 \mathrm{~m}$ deep. F2 is right-lateral strike-slip fault is cut by F3 normal fault with dextral strike-slip component, I) Karaçat mine, its litology and position of mineralization for current day, J) Mineralized breccias of the main thrust fault zone in Karaçat iron mine, K) Strike-slip faults cut hematite deposits in mine, L) Contraxional duplex structures caused by compressional regime in the western section of Karaçat mine. 
len yatakta ortalama \% $55 \mathrm{Fe}$ tenörlü 30 milyon ton rezerv bulunmaktadır. Yatakta süperjen koșullarda olușmuș götit ve limonit cevherleri de ișletilmektedir.

İnceleme alanının güneybatısında Karakızoluğu Tepe'de yer alan Karakızoluğu demir yatağı diğer yataklardan farklı olarak yan kayacı Jura-Kretase yașlı metakonglomeratik seviyeler içerisinde olup cevher, breșik hematit cevheri șeklindedir. Bu formasyonu olușturan kayaçlar içinde belli bölgelerde plastik deformasyonun ürünü olan uzama yapıları meydana gelmiș olup ve bu zamanda bir makaslama zonunun geliștiğini göstermektedir. Yatak KD-GB doğrultulu ve $50^{\circ}$ ile güneydoğuya eğimli bir ters fay dokanağında bulunmaktadır. Yaklașık 300 m uzunluğunda olan bu Karakızoluğu Fayı'nın düzlemi üzerindeki kayma çiziklerinin yan yatım değeri $75^{\circ}$ 'dir.

Çalışma alanındaki yer alan diğer küçük demir yatakları da fay konrollü olup bu yataklarda hidrotermal hematit, süperjen koșullarda zenginleșmiș götit ve limonit cevherleşmeleri hâkimdir. Faylar genellikle KD-GB doğrultu ve GB'ya eğimli ters faylardır. Buradaki hematit ve götit cevherleșmelerine barit ve kalsit mineralleri eşlik etmektedir. Baritlerde yapılan sıvı kapanım çalıșmaları (Keskin vd., 2010b) bu yataklarda olușan hematit, götit gibi cevherleșmelerin çok düşük sıcaklıklarda oluştuğu ve cevherin kaynağı olan hidrotermal çözeltilerin sığ derinlikli bu faylardan geçtiğini göstermektedir.

Yukarıdaki arazi bulguları ısığında fay zonları, cevher olușumunda kanal görevi görebilmektedir (Şekil 5G). $\mathrm{Bu}$ zonlar, derinlerden gelen cevher tașıyan hidrotermal sıvıların geçiși sağlayarak, uygun ortamlarda maden yatak ve zuhurlarını olușturmaktadır. Böylece cevherleșme sonrası faylar tarafından kontrol edilen maden yataklarının olușum yerlerini de bulmak mümkündür. (Şekil 5F, 5J) (Miller ve Wilson, 2004a; Keskin vd., 2010a). Farklı özelliklerdeki fay atım verilerinin, çoğunlukla maden yataklarını kontrol eden eski fayların yeniden ișlemesi ile ilișkili (cevherleșme öncesi faylar) olabileceği düșünülmektedir. Miller ve Wilson (2004a)'nun yapmıș olduğu çalıșmalarda, fay sistemlerinin yapısal analizlerindeki anahtar problemlerden olan stres alanı doğrultusundaki değişiklikler ve ana stresin büyüklüğündeki değișimlerin cevherleșmeyle olan ilișkisi ortaya konulmuștur. Böylelikle zamanla değișen stress yönlerine bağlı olarak cevher kütlesinin olușum modeli ortaya çıkarılmaktadır.

Maden yataklarından elde edilen bu gibi yapısal bilgilerin yardımı ile bir fayın tavan bloğuna bağı hareket yönleri, sıkıșma ve gerilme yönleri hesaplanmakta ve araștırılan faya ait verilerin asal gerilme değișimleri ortaya konularak yeni yatakların bulunmasına olanak sağlanmaktadır. Bu bağlamda, dünyada faylanma ile ilișkili maden yataklarının ortaya konulmasında birçok araștırma yapılmıștır (örneğin; Taylor vd., 2001; Abia vd., 2003; Brown vd., 2004; McLellan vd., 2004; Miller ve Wilson, 2004b; David, 2008; Ghebreab vd., 2009). Bu çalıșmalarda tektonizma ile eş yaşlı meteorik model savunulmuştur. Bu hidrotermal modelde yüzey sıvıları, aktif kara önü kıvrım ve bindirme kuşaklarının oluşumu ile genişlemeli tektonik esnasında çökme sırasında orojenik kușağa sızmaktadır. Bu sıvılar daha önce var olan cevherleșmeleri oksidasyona uğratarak hematite dönüștürmekte ve Mt. Whaleback gibi yapısal kontrollü zonlarda devasa hematit yataklarını olușturmaktadır.

Bu bilgilerin yanında hipotetik olarak, bașlangıçta genișleme rejiminin etkili olduğu bir alanda, buna bağlı olarak normal fayların olușması ve eș zamanlı olarak bu zayıflık zonlarına hidrotermal akıșkanların yerleșmesi mümkündür (cevherleșme ile eș yașlı fay). Daha sonra pozitif terslenme tektoniğine (bașlangıçta genișlemeli tektonik fazda çalıșan bir fayın ters faya dönüșmesi) bağlı olarak fay zonlarına yerleșmiș cevherlerin cevherleșme sonrası faylar tarafından kesilip atıma uğraması olasıdır.

Bu olasılıklar göz önüne alınarak inceleme alanındaki fayların cevherleșme ile olan ilișkilerini ortaya koymak amacıyla, hemen hemen tüm birimleri etkilemiș olan fay düzlemlerinden 144 adet ölçüm alınmıștır. Diğer çalıșmalardan farklı olarak bu bölümde fayları doğrultularına göre değil de, ilk etapta türlerine göre ayırıp değerlendirilmesinin daha doğru olacağı düșünülmüștür. Böylelikle cevherleșmenin hangi deformasyon evresinde oluștuğunun belirlenmesi daha da mümkün olmaktadır. Bu amaçla faylara bağlı verilerden yapılan Kutupsal eșit alan neti yardımıyla steorografik projeksiyonlar hazırlanmıștır. Bu faylar türleri açısından dört grupta belirlenmiş olup bunlar: normal, ters, doğrultu atımlı ve türü belirlenemeyen faylar olarak gruplandırılmıştır (Şekil 6). İnceleme alanında ölçülen faylardan; normal fayların yaklaşık BKB-DGD doğrultulu, ters fayların KD-GB doğrultulu, doğrultu atımlı fayların KB-GD, KD-GB ve türü belirlenemeyen fayların KB-GD ve KD-GB hakim doğrultularda olduğu görülmektedir (Șekil 6A-D). Bu fayları olușturan muhtemel asal gerilme eksenlerinin konumu Șekil 7'de gösterilmiștir. Asal gerilme konumlarına göre inceleme alanında normal fayları olușturan gerilme kuvvetlerinin muhtemel yönleri KKB-GGD yönlü açılma kuvvetleridir (Șekil 7A). Ters fayları meydana ge- 
tiren muhtemel sıkıșma yönlerinin konumu K-G yönlü sıkıșma kuvvetlerinin etkisini göstermektedir (Șekil 7B). Çalıșma alanındaki doğrultu atımlı fayların olușumu bölgenin batısında yer alan OAFZ ile ilișkili olup muhtemelen BKB-DKD yönlü sıkıșma kuvvetleriyle ilișkilidir (Șekil 7C). İnceleme alanında diğer kırık düzlemlerin olușumu ise farklı gerilme yönlerinin bölgeyi etkilemesiyle ilișkili olmalıdır (Șekil 7D).

Yukarıda fayların gelișimini sağlayan en büyük $\left(\sigma_{1}\right)$ ve en küçük $\left(\sigma_{3}\right)$ asal gerilme eksen konumlarının bölgede etkili olan kıvrımlanma sistemleriyle olan ilișkilerinin de ortaya konulması gerekmektedir. Attepe ve çevresi demir yataklarının bulunduğu inceleme alanında kıvrım tektoniğini șu ana kadar ortaya koyabilecek herhangi bir çalıșma yapılmamıștır. Harita alanında makroskopik olarak gözlenen sünümlü deformasyon ürünü olan bu kıvrımlar Prekambriyen, Alt Kambriyen, Ordovisiyen ve Jura-Kretase yașlı metamorfik kayaçların içinde lokal ölçekte olup genellikle krenülasyon klivajlarının olușturduğu kıvrımlar, kink bantları ve küçük ölçekte antiklinal ve senklinal yapılarıdır. Ayrıca Orta-Üst Kambriyen kireçtașları içinde tektonizmaya bağlı sürüklenme kıvrımları, flat-ve-flat yapıları ve tabaka durușlarına göre senklinal ve antiklinal gibi yapılar gelișmiștir. Arazi gözlemleri bölgedeki kayalarda, KB-GD, D-B ve KD-GB yönelimli kıvrımlanmaların varlığına ișaret etmekte ve yönlü bir yapı izlenmektedir. Bu düzlemsel yapılardan hazırlanan $\pi$ ve $\beta$ diyagramları, formasyon ve yaș olarak ayrı ayrı değerlendirilip mümkün kıvrımların yönelimleri belirlenmiștir Bu amaçla 601 adet metamorfik kayaç ölçümü ile 111 adet tabaka ölçüsü alınıp hazırlanan diyagramların özeti Șekil 8'de verilmiștir. Böylece bölgedeki kıvrımlanmaları olușturan her yaș ve formasyon aralığında gelișen sıkıșma yönleri fay kinematik verileriyle kıyaslanarak, cevherleșmenin hangi deformasyon fazında geliștiği ortaya çıkarılmıștır.

Fay düzlemi kayma verileri ve kıvrım analizlerine göre, KKB-GGD yönlü sıkıșma ve KD-GB yönlü gerilme kuvvetlerinin etkisi bölgede hakim olmuștur. İnceleme alanı tektonik olarak iki ana sol yanal doğrultu atımIı fay zonu arasında yer almaktadır. Orta Anadolu ve Göksu-Yazıyurdu Fay Zonları arasında kalan inceleme alanında, bu iki ana yapı arasında KD-GB uzanımlı geniș bir sol yanal makaslama zonu gelișmiștir. Bu deformasyonda Doğu Anadolu ve Orta Anadolu Fay zonları ile sınırlı deformasyon alanında etkin olması hipotetik olarak beklenen K-G yönlü sıkıșma, fay düzlemi kayma verilerine göre KD-GB yönüne kaymıștır. $B u$ durum, Orta Anadolu ve Doğu Anadolu sol yanal fay zonları arasındaki blok rotasyonla açıklanabilir. (Koç ve Kaymakçı, 2013). Buna göre, iki ana doğrultu atımlı fay zonu arasında kalan bölge saat yönünde yaklașık 45 derece rotasyona uğramıștır. Anadolu levhacığında yapılan paleomanyetik, paleotektonik, neotektonik, gravite ve manyetik çalıșmalar ile (Mc Kenzie, 1972; Dewey vd., 1973; Dewey ve Șengör, 1979; Șengör ve Yılmaz,1981; Tatar vd., 1995; Koçyiğit ve Bayhan, 1998; Yılmaz, 2004; Taymaz vd., 2007; Akın ve Çiftçi, 2011), bu levhacığı sınırlayan faylar ile bu plaka içinde olușan fayların KKB-GGD yönlü bir bölgesel sıkıșma olduğunu göstermekte, bu sıkıșma rejiminin Miyosen sonu Arap plakasının kuzeye hareket ederek Anadolu levhacığını sıkıştırması sonucu meydana gelen farklı gerilme yönleriyle açıklanabilmektedir (Şekil 1). Bu sıkıșma yönünün inceleme alanında elde edilen verilerle uyumlu olduğu görülmektedir. Bu çalıșmalardan Akın ve Çiftçi (2011), tüm Türkiye'de pafta bazıı yürüttükleri manyetik, gravite, paleotektonik ve neotektonik çalışmalarla, yapısal süreksizliklerin olușan maden yataklarıyla olan ilișkisini ve gerilme fazlarını ortaya koymușlardır. Bu gerilme fazlarının inceleme alanında kalan kesimindeki sıkıșma rejimiyle uyumlu olduğu görülmekte ve günümüzde ișletilen hidrotermal-metazomatik kökenli geç evre hematit ve süperjen koșullarda olușmuș götit, limonit gibi oksit-hidroksit cevherleșmelerini olușturan sistemle ilișkili olduğu düșünülmektedir.

\section{CEVHERLEȘME ÖZELLiKLERi}

Attepe demir yataklarındaki cevherleșmelerin jeolojisine yönelik birçok çalıșma yapılmıștır. Bu çalıșmaların büyük bir çoğunluğunda, günümüzde ișletilen ve yukarıda yapısal sentezi anlatılan hematit-götit-limonit gibi oksit-hidroksit cevherleșmeleri detaylı olarak ortaya konulmasına rağmen, köken konusunda tektonik ağırlıklı yeterince çalıșma yapılmamıștır (Küpeli, 1986; Küpeli, 1991; Dağlıoğlu ve Bahçeci, 1999; Dağlıoğlu ve Arda, 2000; Arda vd., 2008; Dayan vd., 2008; Tiringa vd., 2009). Yapılan çalıșmalarda cevherleșme 5 ayrı seviyede gözlenmiștir (Keskin, 2016c). Bu çalıșmalardan farklı olarak ilk 4 seviyede olușan cevher olușumu aynı, 5. seviyede olușan cevher olușumu, oluștuğu yan kayaç özelliğinden dolayı ayrı sınıflandırılmıștır. Bunlar, (1) Prekambriyen yașlı birim içinde sedimanter siderit ve pirit, (2) Alt Kambriyen yașlı kuvarsit ile Orta-Üst Kambriyen yașlı kireçtașları arasında genellikle hidrotermal-dolgu tipi hematit, götit, (3) Orta Kambriyen yașlı kireçtașları içinde genellikle hidrotermal-metazomatik hematit, siderit, ankerit ve süperjen götit-limonit, (4) Ordovisiyen içindeki kalkșist mercekleri ile șeyller içerisinde hidrotermal siderit ve hematit ve (5) Jura-Kretase 


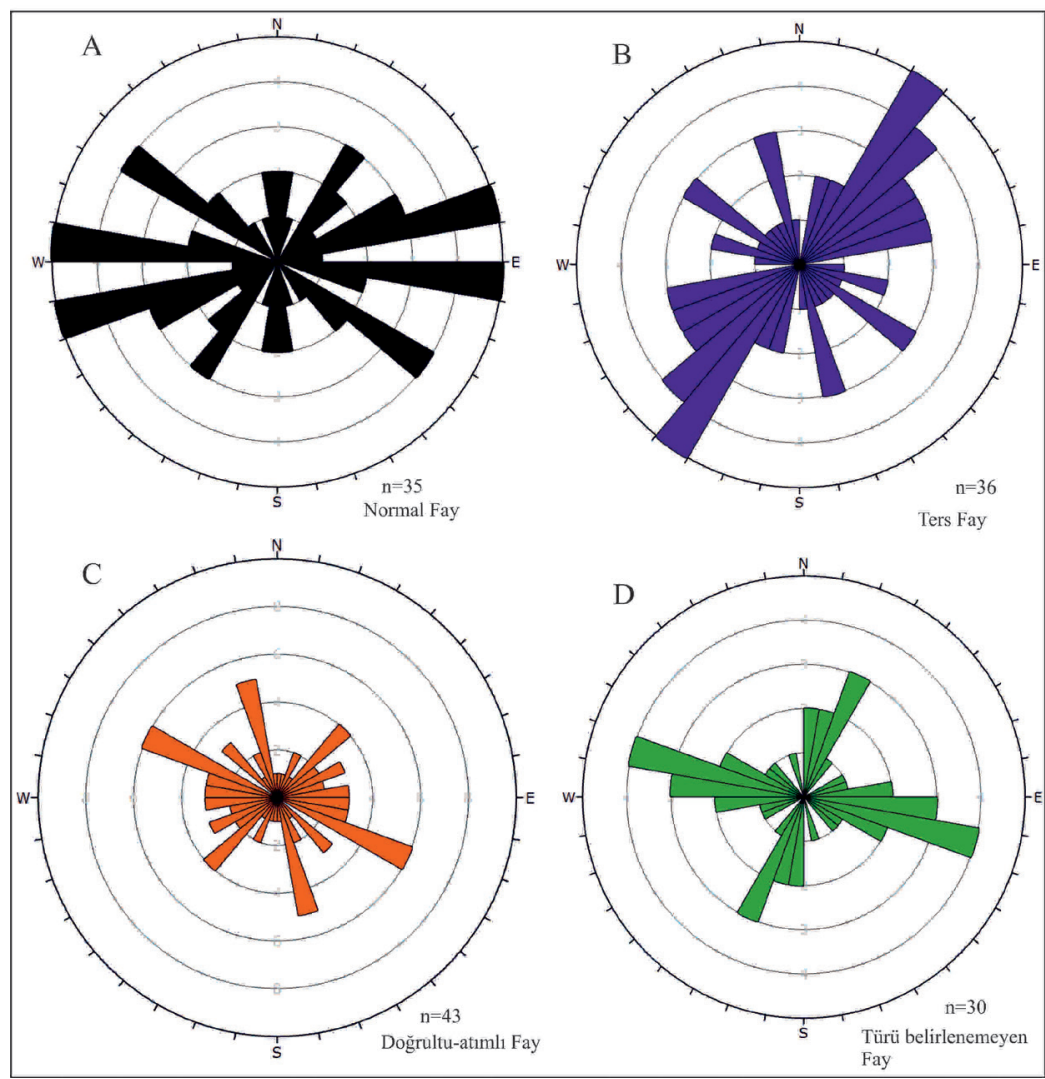

Șekil 6. Çalıșma alanındaki fayların doğrultu gül diyagramları; A) Normal fay, B) Ters fay, C) Doğrultu atımlı fay, D) Türü belirlenemeyen faylar.

Figure 6. Fault directions of rose diagrams in the study area; A) Normal fault, B) Reverse fault, C) Strike-slip fault, D) Undetermined faults.

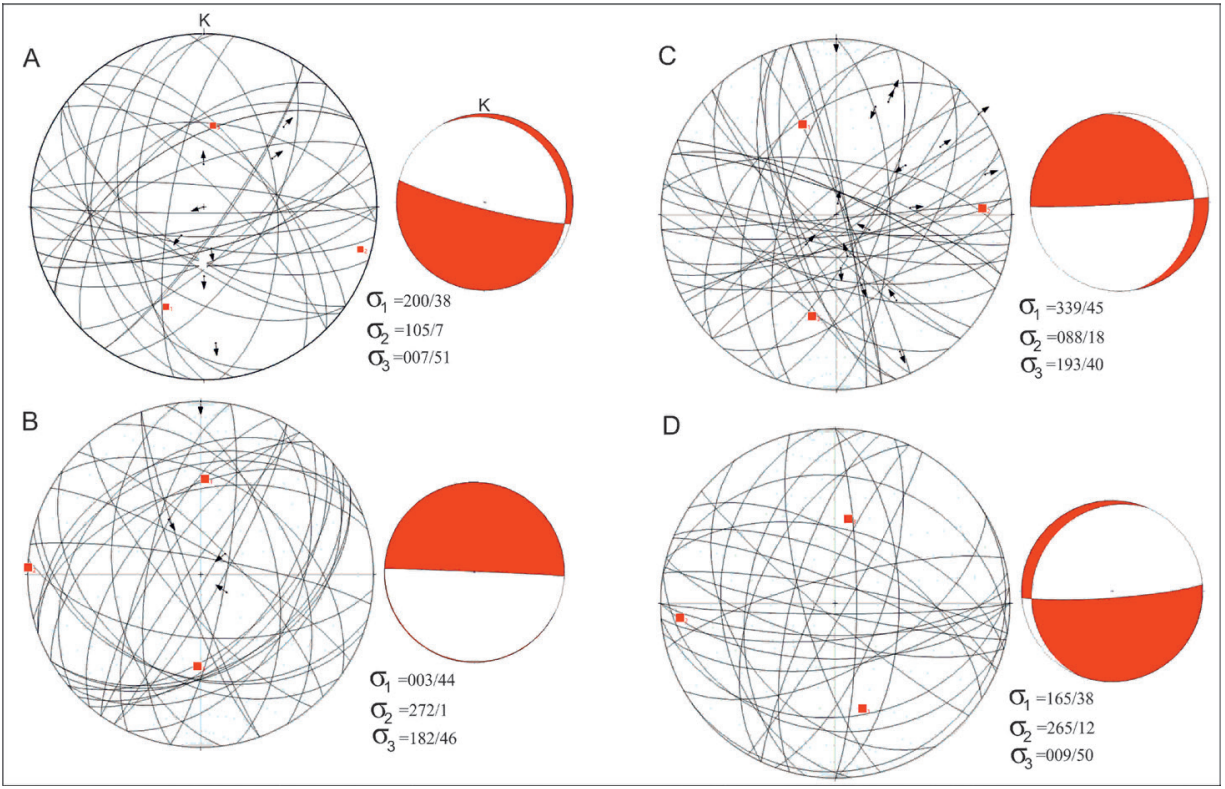

Șekil 7. Çalıșma alanındaki tüm fayların en büyük ve en küçük asal gerilme konumlarını gösteren diyagramlar; A) Normal fay, B) Ters fay, C) Doğrultu atımlı fay, D) Türü belirlenemeyen faylar.

Figure 7. The diagrams show the locations of maximum and minimum principal stress of all faults in the study area; A) Normal fault, B) Reverse fault, C) Strike-slip fault, D) Undetermined faults. 


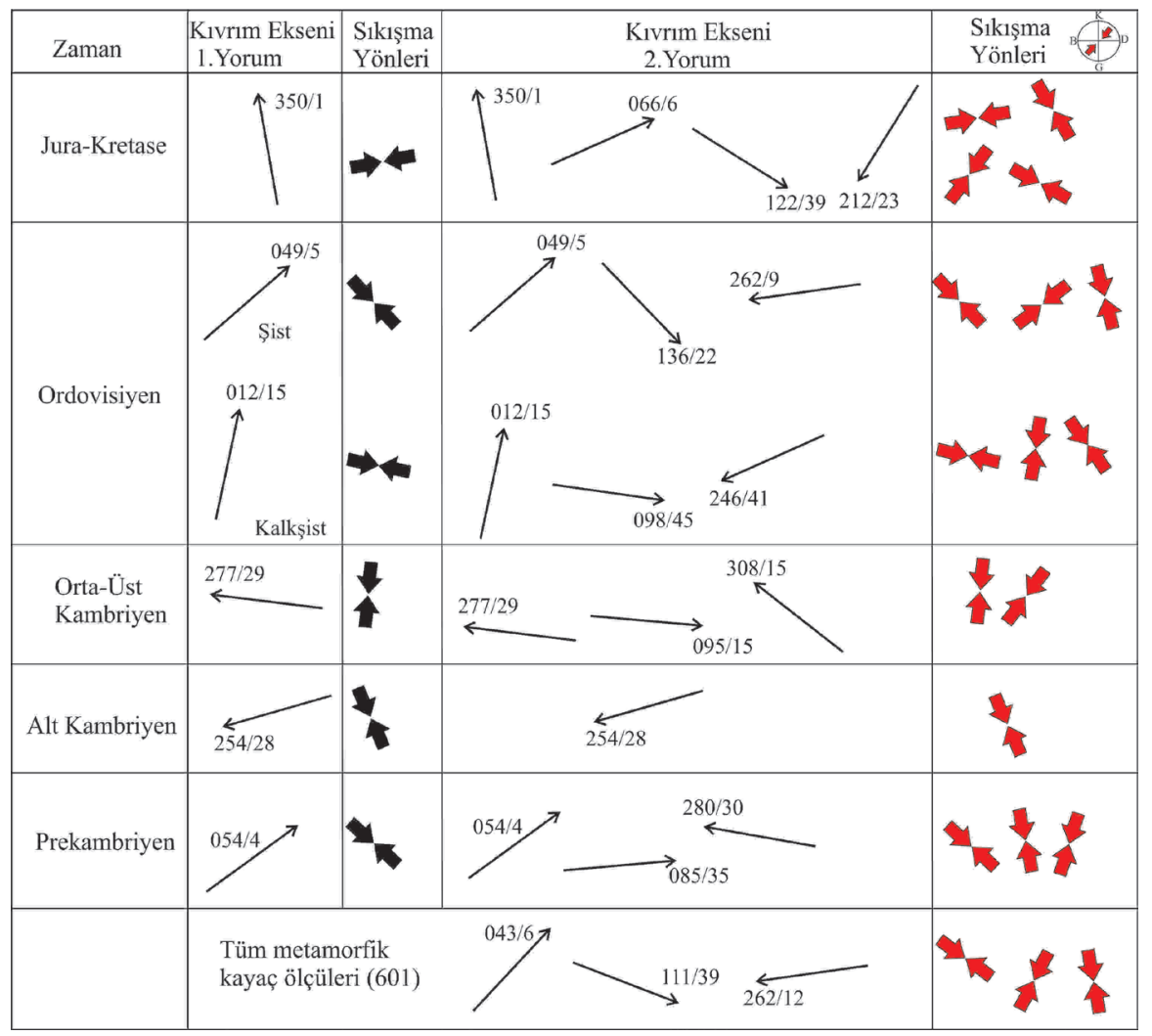

Șekil 8. İnceleme alanındaki kıvrımların formasyon ve yașlara göre olası kıvrım eksenleri ve sıkıșma yönlerinin konumu.

Figure 8. The location of the possible fold axes and compression directions of folds with respect to the formation and ages in the study area.

yașlı metakonglomeralar içerisinde breșik hematit cevheri olarak görülmektedir.

Siderit olușumları, Prekambriyen yașlı metapelit, sleyt, fillit, șeyl ve metakumtașlarıyla uyumlu olarak ve yine Prekambriyen yașlı birimler içindeki volkanik kayaçlarla (metavolkano-tortul, andezitik, bazaltik tüf) birlikte görülmektedir (Șekil 9). Piritler formasyon içindeki birimlerde saçınımlı olarak izlenmektedir (Șekil 9D). Çok az sayıdaki çalışma Prekambriyen yașlı birincil cevherin sedimanter özellikte olduğu ve ayrıca, tektonik hatlara bağlı büyük siderit ve ankerit kütleleri șeklinde görüldüğünü (Ünlü ve Stendal, 1989) ve cevherleșmenin daha sonradan hidrotermal-metazomatik etkiyle hematitleșmeye (Şekil 9C) uğradığını göstermektedir. Çalıșma alanında ișletilen yataklardan sadece Attepe demir yatağı içinde ve Karaçat demir yatağının 2 km kuzeybatısındaki Demirçoluğu Dere içinde birincil kökenli sideritler ortaya konulmuștur (Șekil 9). Ayrıca çalıșma alanının güneyinde Bekirhacılı Köyü'nde (Arda vd., 2009; Tiringa vd., 2009; Tiringa, 2016) Tașlık demir madeninde de ilksel siderit olușumları tespit edilmiștir. Șistoziteye uyumlu sin-sedimanter siderit $\left(\mathrm{FeCO}_{3}\right)$ cevherleșmelerinin varlığı (Șekil 9E ve F) inceleme alanına farklı bir bakıș açısı kazandırmıștır. Prekambriyen birimler içinde metamorfik ve volkanik kayaçlarla birarada tespit edilen (Şekil 9G ve H) bu demir karbonat cevherleșmelerinden çözünen demirin, Kretase sonrası ofiyolit yerleșiminden sonraki dönemde gelişen faylarla yukarı tașınması ve Orta-Üst Kambriyen yașlı kireçtașları ile daha genç birimleri metazomatize ederek bugünkü ișletilen geç evre oksit-hidroksit yataklarını olușturduğu görülmektedir (Șekil 5).

Çalışma alanındaki maden yataklarının içinde ve çevresinde bulunan birincil (sin-sedimanter) ve ikincil (hidrotermal) siderit $\left(\mathrm{FeCO}_{3}\right)$ örneklerinde yapılan parlatma ve SEM-EDAX (EDS) çalışmaları ile Prekambriyen çökeller içindeki sideritlerin mineral parajenezi ve kökeni ortaya konulmak istenmiştir. İlksel oluşumlu masif sideritlerde makro olarak kristallenme belirgin değildir. İkincil oluşumlu sideritlerde makro olarak dilinimler daha belirgin ve bal mumu kristali şeklindedir 
(Şekil 9B). Bu çalıșmalarda sideritten çözünme ağsı hematit, götit ve limonit cevherleșmeleri tespit edilmiștir (Șekil 9C ve 10). El örneğinde kireçtașına benzeyen birincil kökenli masif görünümlü sideritlerin parlak kesitlerinde (Şekil 10A), koyu gri yansıma rengi ve açık kahverengi iç yansıma belirgindir (Șekil 10B). Parlak kesitlerde rombohedrik kristalli sideritlerin hematitler tarafından ornatıldığı ve her ikisinin de kenarlarından ve çatlaklarından itibaren götitleștiği izlenmektedir (Şekil 10C ve E). Hematit mineralleri açık gri renk tonlarında olup daha düzgün yüzeylere sahip ve özșekili kristaller halindedir. Ayrıca kesitlerde kalsit dilinimleri içinde de görüldüğü gibi karbonat iskelet dokusu ve olușan boșluklarda hidratasyon sonucu kısmen kolloform yapılı götitleșmiș hematitler izlenmektedir (Şekil 10D). Burada demirli karbonatlar hematitleșmiș, lepidokrozitleșmiș ve götitleșmiș olup hematitlerde görülen küresel yapılar tekrarlanan rekristalizasyonu göstermektedir (Șekil 10F). Cevherleșme sonrası tektonik rejimde gelișen deformasyon sonucu demir karbonat mineralleri olan sideritler parçalanarak breșik yapı kazanmıșlardır (Şekil 10G). Demir oksit minerallerinin yanında pirit gibi sülfit mineralleri de gözlenmektedir. Deformasyonun ileri safhalarında mineraller arasında ve içinde özșekilli kristaller halinde olan piritler kataklastik yapılı olarak görülmektedir (Șekil 10H).

Cevher mikroskopisi çalışmaları ile ayırt edilemeyen mineraller SEM çalıșmaları sonucu ortaya konulmuștur. SEM-EDS çalıșmaları ve optik mikroskop sonuçlarına göre sedimanter sideritlerin mineral parajenezi, magnezyo-siderit, hematit, götit, limonit, ankerit, pirit, lepidokrozit, dolomit, kalsit, kuvars, aktinolit, apatit ve biyotittir (Șekil 10, 12). Biyotit ve aktinolit gibi mafik kayaç yapıcı minerallerin bulunması (Şekil 11C, E ve Șekil 12H) bu Prekambriyen yașlı birimler içinde olușan siderit cevherleșmelerinin olușumu sırasında, volkanik bir etkinin (olasılıkla volkanik kayaçlardan çözünen demir) olduğuna ișaret etmektedir. Arazi verileri de bu bulguları (Șekil 9) desteklemektedir. Cevherleșme içinde grimsi renk tonlarında ve küçük kümelenme șeklinde görülen apatit gibi gang minerallerinin olușumu (Şekil 11C ve Șekil 12C) diyajenetik süreçlerle ilișkili olabilmektedir (Kholodov ve Butuzova, 2004; Bolhar vd., 2005).

\section{OKSIJEN $\left(\delta^{18} O\right)$ VE KARBON DURAYLI $\left(\delta^{13} \mathrm{C}\right)$ IZOTOP JEOKIMYASI}

Attepe ve çevresindeki demir yataklarında günümüzde işletilen geç evre hematit ve süperjen götit- limonit yataklarının olușumu Emirgazi Formasyonu içindeki metapelitik ve volkanik kayaçlarla ilișkili sin-sedimanter olușumlu siderit cevherleşmeleriyle doğrudan ilişkilidir (Keskin ve Ünlü, 2016a, b). Bu siderit cevherleșmelerinin petrografik özellikleri ve duraylı izotop bileșimleri, onların çökelme ortamları içinde veya diyajenetik olușumları sırasındaki çökelme ve dağılımlarını ortaya çıkarma açısından önemlidir. Karbonat minerallerinin geniș çökelme ortamları (Șekil 9) ve diyajenetik rejimler içindeki kökeni, izotopik bileșimleri ve dağılımı birçok çalıșmayla ortaya konulmuștur (Hangari vd., 1980; Pye vd.,1990; Morad vd., 1994; Huggett vd., 2000; Fernandez-Nieto vd., 2003; Wang vd., 2015). Sideritler tipik olarak indirgeyici, sülfür bakımından fakir ortamlarda çökelir ve oksijen ve sülfürün az olduğu suboksik, metanca zengin jeokimyasal ortamlarda gelișir (Hemi, 1985; Morad,1998; El-ghali vd., 2006). Sideritlerin izotop jeokimyası onların oluștuğu ortamdaki sıvıların denizel, meteorik veya denizel-meteorik bileșimli olup olmadığını da göstermektedir. Bu amaçla inceleme alanında daha önce yapılan çalıșmalarda, doğrudan birincil kökenli siderit cevherleșmelerinin olușum koșulları ortaya konulmamıștır. Genellikle sonradan metazomatik-hidrotermal süreçlerde olușan ve Orta-Üst Kambriyen yașlı kireçtașları içinde meydana gelen geç evre oksit-hidroksit-sülfit-sülfat cevherleșmeleri ile ikincil siderit olușumları üzerinde $\mathrm{O}, \mathrm{Sr}, \mathrm{S}$ ve $\mathrm{C}$ izotop çalışmaları yapılmıștır (Küpeli vd., 2007). Bu amaçla inceleme alanında yer alan demir yatakları ve çevresindeki mostralardan sistematik olarak alınan (Șekil 9) birincil (sin-sedimanter) ve ikincil (hidrotermal) 11 adet siderit $\left(\mathrm{FeCO}_{3}\right)$ örneğinden duraylı izotop çalıșmaları yürütülerek cevherleșmenin kökeni hakkında yorumlamalara gidilmiștir. Analizler Arizona Üniversitesi, İzotop laboratuarlarında yapıImıștır.

Analizlerde siderit örneklerinin $\delta^{18} \mathrm{O}$ ve $\delta^{13} \mathrm{C}$ değerleri, bir gaz-oranlı kütle spektrometrisine (Finnigan MAT 252) bağlı otomatik bir karbonat hazırlayıcısı (KielIII) kullanılarak ölçülmüştür. Toz numuneler $70^{\circ} \mathrm{C}$ 'de vakum altında kurutulmuş ve fosforik asit ile reaksiyona sokulmuștur. İzotop oranı ölçümü, NBS-18 ve NBS-19 uluslararası standartlarına uygun, tekrarlanan ölçümlerine dayalı olarak (hassasiyet $\delta^{18} \mathrm{O}$ için \pm $\% 00.10$ ve (1 sigma) $\delta^{13} \mathrm{C}$ için $\left.\pm \% 0.08\right)$ kalibre edilmektedir (Gilg vd., 2003). Tüm izotop sonuçları uluslararası PDB (Pee Dee Belemnite) ve V-SMOW (Vienna-standart Ortalama Okyanus Suyu) standartlarına göre per mil olarak kayıt altına alınmıștır (Çizelge 1). Birincil sideritlerdeki $\delta^{13} C_{P D B}$ değerleri $\% o-0.71$ 


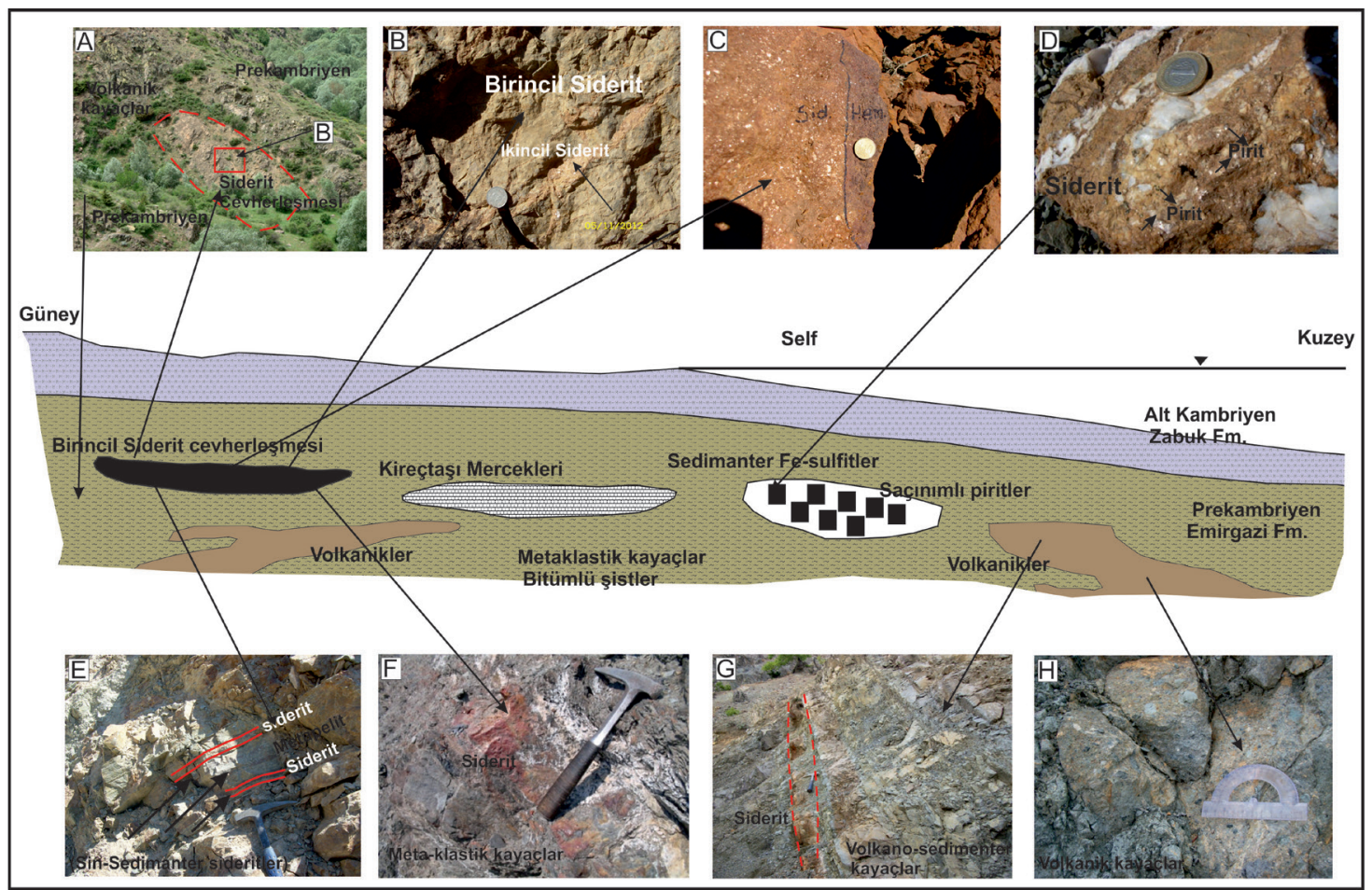

Şekil 9. Prekambriyen yaşlı birimler içinden alınan birincil sideritlerin arazi görünümü. Birincil sideritlerin oluşumu formasyon içindeki birimlerle uyumlu olup volkanik kayaçlarla ilişkili olabileceği görülmektedir (Paleocoğrafik profil Demirel ve Kozlu, 1997'den değiștirilerek alınmıștır) (Șekil 9F, Dayan 2007'den alınmıștır). Şekil açıklamaları için lütfen metne bakınız.

Figure 9. Field photos of primary siderite taken by Precambrian aged outcrops. The formation of primary mineralizations is compatible with the rocks in formation and, may be related to volcanic rocks (Paleo-geographic profile modified from Demirel and Kozlu, 1997) (Figure 9F taken by Dayan, 2007). Please see the text for figure explanations.

ile \%o-1.62 arasında, $\delta^{18} \mathrm{O}_{\mathrm{PDB}}$ değerleri \%o-9.95 ile $\%$-10.68 arasındadır. Buna karșın ikincil olușumlu sideritlerdeki $\delta^{13} \mathrm{C}_{\mathrm{PDB}}$ değerleri \%o-6.57 ile \%o-7.94 arasında, $\delta^{18} \mathrm{O}_{\text {vPDB }}$ değerleri de \%o-10.29 ile \%o-11.28 arasındadır (Çizelge 1). Analiz sonuçlarına göre birincil kökenli siderit cevherleșmeleri, denizel ortamlarda olușan ve çökelen karbonatlarda meydana gelen düșük manganlı diyajenetik siderit olușumlarına, ikincil sideritler ise hidrotermal kökenli demir olușumlarına ișaret etmektedir (Șekil 13).

Attepe ve çevresindeki demir yataklarına yönelik önceden yapılan izotop çalıșmaları verileri derlenerek bir diyagram üzerinde gösterilmiștir (Șekil 14). Dolayısıyla çalıșma alanında daha önce elde edilen oksijen ve karbon izotop sonuçları bu çalıșmada elde edilen verilerle kıyaslanmıștır. Önceki çalışmalarda rekristalize olmuș Orta-Üst Kambriyen yașlı kireçtașlarından (13 adet) ve damar-tip olarak isimlendirilen cevherler içindeki sideritlerden (14 adet) oksijen ve karbon izotop çalışmaları yapmışıı (Küpeli vd., 2007).
Kireçtașlarındaki $\delta^{13} \mathrm{C}_{\mathrm{PDB}}$ değerleri \%o-0.80 ile \% 2.30 arasında, $\delta^{18} \mathrm{O}_{\text {vsmow }}$ değerleri de \% 16.18 ile $\% 21.90$ arasındadır. Sideritlerdeki $\delta^{13} \mathrm{C}_{\mathrm{PDB}}$ değerleri \%o-8.20 ile $\% 10.10$ arasında, $\delta^{18} \mathrm{O}_{\text {vsmow }}$ değerleri de $\% 17.50$ ile \%18.30 arasındadır. Bu çalıșmada primer sideritlerden elde edilen $\delta^{18} \mathrm{O}_{\text {vsmow }}$ değerleri de \%o19.80 ile \% 20.66 arasında, ikincil olușumlu sideritlerden elde edilen $\delta^{18} \mathrm{O}_{\text {vsmow }}$ değerleri de \%o18.50 ile \%20.30 arasındadır. Elde edilen verilen diyagram üzerinde gösterildiğinde (Șekil 14), birincil siderit cevherleșmelerinin olușum ortamlarınınnın, denizel karbonatların (Baker ve Fallick, 1989; Hoefs,1997) oluștuğu alanda ve karbonat çözülmesinin bașlangıç safhalarında oluștuğunu göstermektedir. İkincil geç evre hidrotermal olușumlu sideritler ise önceki çalıșmada elde edilen sideritlerin izotop sonuçlarılya aynı alana düșmektedir. Bu da önceki çalışmada siderit olușumlarının birincil değil, ikincil, geç evre hidrotermal cevherleșmeler olduğunu göstermektedir. Birincil kökenli düșük manganlı sin-sedimanter siderit cevherleșmerindeki $\delta^{13} \mathrm{C}_{\mathrm{PDB}}$ değerlerinin 0'a yakın olması, bunların denizel 

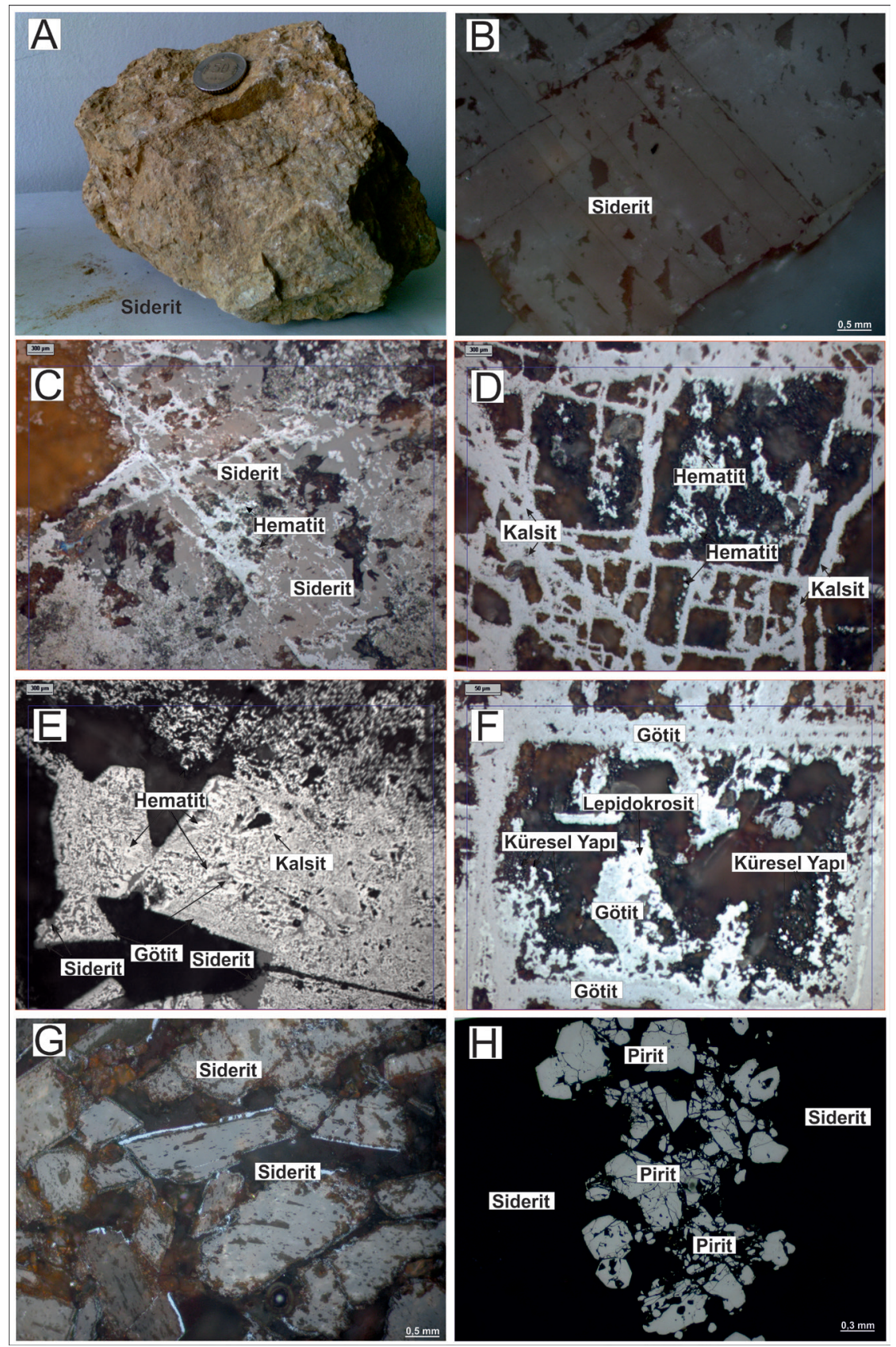

Şekil 10. Masif birincil siderit örneklerindeki mineral parajenezi. A) Prekambriyen birimler içinde olușan masif birincil siderit cevherleșmesi, B) Rombohedrik yapılı siderit kristali, C) Siderit minerallerinin ornatımı sonucu olușan hematit cevherleșmesi, D) Karbonat iskelet dokusu içinde kalsitlerin yerini alan kolloform yapılı götitleșmiș hematitler, E) Siderit kristallerinin kenarlarından itibaren hematit ve götit minerallerine dönüșümü, F) Rekristalizasyon sırasında meydana gelen küresel yapılar ve kolloform yapılı götit-lepidokrosit gibi sulu oksit minerallerinin olușumu, G) Deformasyon sonucu olușan breșik yapılı sideritlerin görünümü, H) Siderit minerali içindeki kataklastik yapılı pirit olușumları.

Figure 10. Mineral paragenesis of primary massive siderite samples. A) Primary massive siderite mineralization occured in Precambrian outcrops, B) Rhombohedral-texture of siderite crystals, C) Hematite mineralization developed by replacement of siderite minerals, D) Colloform-texture of goethite-hematite replacing to calcite in carbonate-frame texture, E) Hematite-goethite mineralization return from the edges of siderite crystals, F) Spheral-textures formed during the recrystallization, and hydrous-oxide minerals occured as colloform-texture goethite- lepidocrocite, G) The view of brecciated-texture of siderite caused by deformation, H) Cataclastic-texture of pyrite occurences in siderite minerals. 

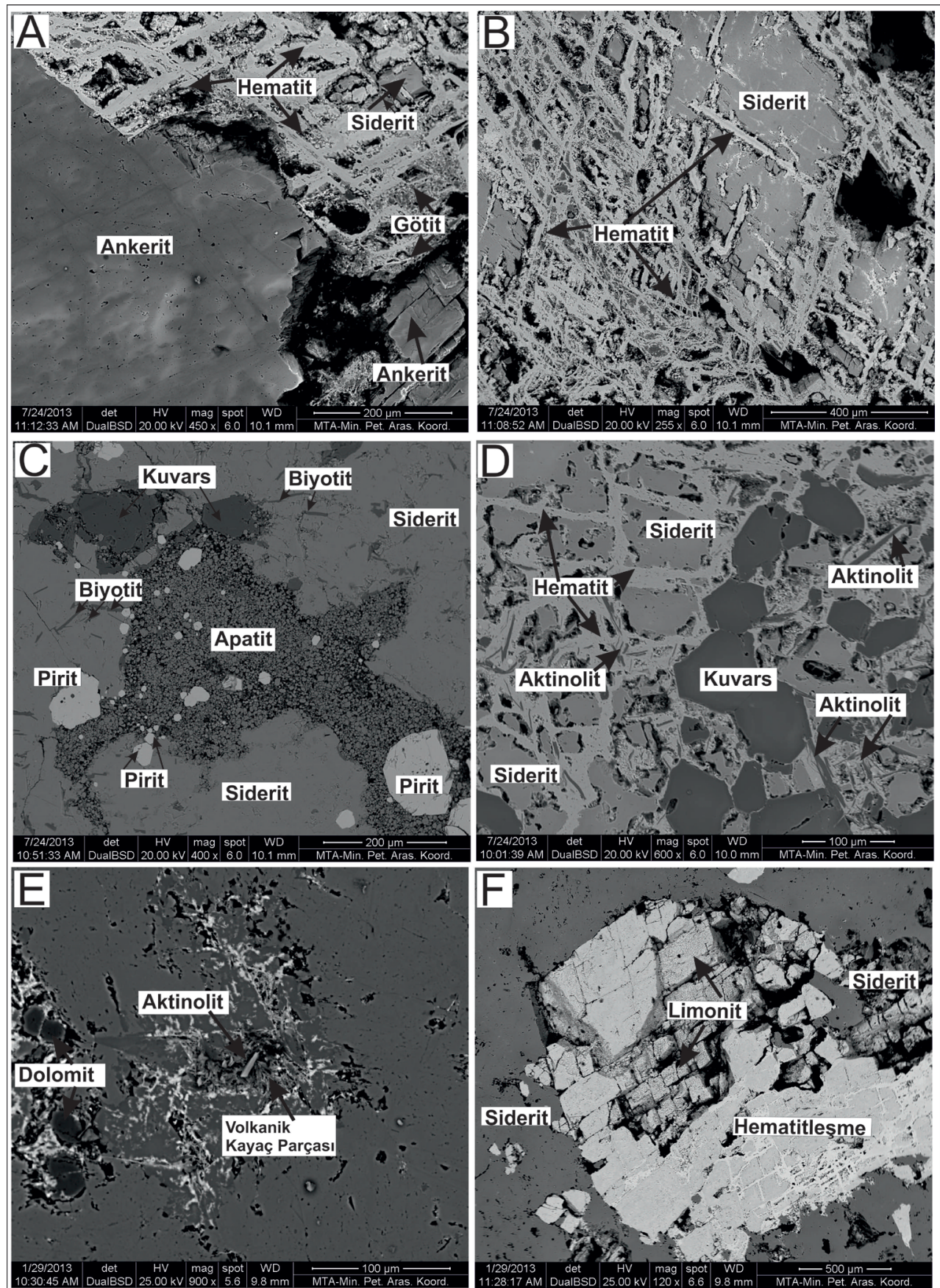

Şekil 11. Bazı birincil siderit minerallerinin SEM-BSE görüntüleri. Demir karbonat minerallerinin; ankerit, götit (A), hematit (A, B ve F) ve limonite $F$ ) dönüșmesi. Hematit olușumları sideritlerin kenar ve çatlaklarından itibaren büyüyüp gelișmektedir. Yarı-özșekilli pirit (C) ve özșekilli ikincil kuvars mineralleri (D) sideritler içerisinde ayırt edilebilmektedir. Ĭğnemsi biyotit (C), ve çubuksu görünümlü aktinolit (D ve E) minerallerinin varlı̆̆ı siderit olușumda volkanik süreçlerinin de etkili olduğuna ișaret etmektedir. Apatit minerallerinin olușumu (C) cevher olușumunda diyajenetik süreçlerin de varlığını belirtmektedir.

Figure 11. SEM-BSE images of some primary siderite minerals. Iron carbonate minerals return to ankerite, goethite (A), hematite (A, B and F) and limonite. Hematite occurences develop and grow from the edge and fractures of siderite minerals. C) Subhedral pyrite and D) euhedral secondary quartz minerals are distinguished in siderite minerals. Presence of some minerals such as styliform-texture biotite (C), and fibroustexture actinolite, indicate the volcanic process may be effective to formation of siderite. The formation of apatite mineralizations $(C)$ indicate the existence of diagenetic processes during the ore formation. 


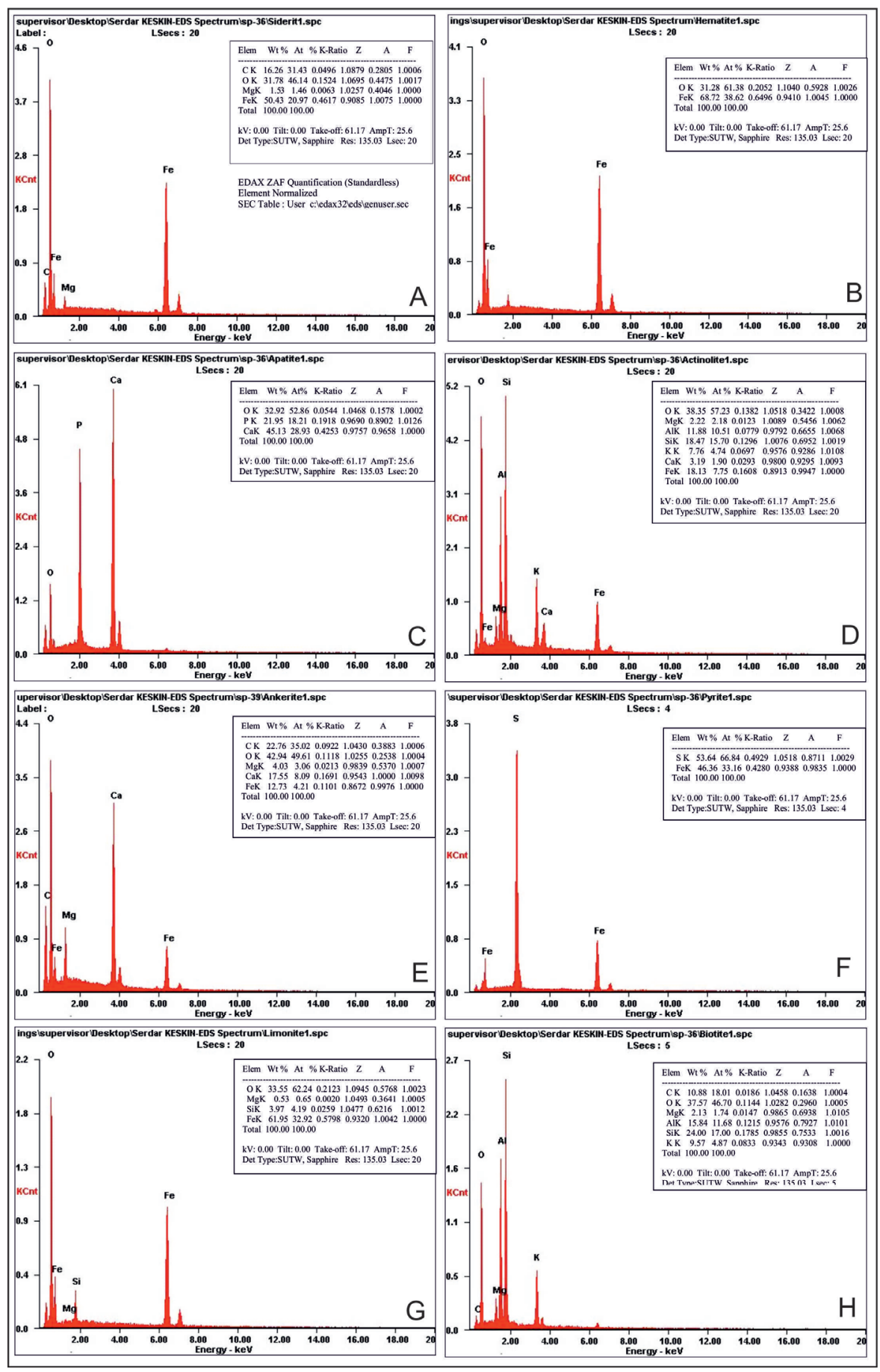

Şekil 12. Prekambriyen birimler içindeki bir kısım birincil sideritlerin SEM-EDS analiz sonuçları. EDS sonuçları (A) siderit $\left(\mathrm{FeCO}_{3}\right)$ cevherleșmeleri içindeki $(\mathrm{B})$ hematit $\left(\mathrm{Fe}_{2} \mathrm{O}_{3}\right),(\mathrm{C})$ apatit $\left(\mathrm{Ca}_{5}\left(\mathrm{PO}_{4}\right)\right)$, (D) aktinolit $\left(\mathrm{Ca}_{2}(\mathrm{Mg}, \mathrm{Fe})_{5} \mathrm{Si}_{8} \mathrm{O}_{22}(\mathrm{OH})_{2}\right)$, (E) ankerit $\left(\mathrm{Ca}(\mathrm{Fe}, \mathrm{Mg})\left(\mathrm{CO}_{3}\right)_{2}\right)$, $(\mathrm{F})$ pirit $\left(\mathrm{FeS}_{2}\right)$, (G) limonit ve $(\mathrm{H})$ biyotit $\left(\mathrm{K}(\mathrm{Mg}, \mathrm{Fe})_{3}(\mathrm{Al}, \mathrm{Fe}) \mathrm{Si}_{3} \mathrm{O}_{10}(\mathrm{OH})_{2}\right)$ minerallerinin oranları ortaya konulmuștur. EDS analizleri siderit cevher örnekleri içinde yapılmıștır.

Figure 12. SEM-EDS analysis results of some primary siderite mineralization in Precambrian outcrops. EDS results demonstrated to minerals rates of $(A)$ siderite $\left(F e C O_{3}\right),(B)$ hematite $\left(F e_{2} O_{3}\right),(C)$, apatite $\left(\mathrm{Ca}_{5}\left(P O_{4}\right)\right),(D)$ actinolite $\left(\mathrm{Ca}_{2}(\mathrm{Mg}, \mathrm{Fe})_{5} \mathrm{Si}_{8} \mathrm{O}_{22}(\mathrm{OH})_{2}\right)$, (E) ankerite $\left(\mathrm{Ca}(\mathrm{Fe}, \mathrm{Mg})\left(\mathrm{CO}_{3}\right)_{2}\right)$, (F) pyrite $\left.(\mathrm{FeS})_{2}\right)$, (G) limonite, and $(\mathrm{H})$ biotite $\left(\mathrm{K}(\mathrm{Mg}, \mathrm{Fe})_{3}(\mathrm{Al}, \mathrm{Fe}) \mathrm{Si}_{3} \mathrm{O}_{10}(\mathrm{OH})_{2}\right)$ in siderite mineralizations. EDS analys/s were conducted in samples of siderite ores. 
karbonatların $(\% \circ 0)$ (Hoefs, 1987) oluștuğu ortamda olduğunu göstermektedir. Ayrıca Kambriyen'den Tersiyere kadar olan zaman aralığında olușan karbonatlı minerallerinin $\delta^{13} \mathrm{C}_{\mathrm{PDB}}$ değerleri 0'a yakındır (Faure,1986). İkincil siderit cevherleșmelerinin $\delta^{13} C_{P D B}$ değerleri de doğal olarak denizel karbonatların $\delta^{13} \mathrm{C}_{\mathrm{PDB}}$ değerlerinden düșüktür ve bu cevherleșmelerin bölgede ișletilen geç evre hidrotermal-metazomatik olușumlu hematit cevherleșmeleriyle birlikte aynı zamanda oluștuğunu ve meteorik sıvıların da olușumda etkili olduğunu göstermektedir (Dayan vd., 2008; Arda vd., 2009). Bu sideritler derinlerden gelen demirce zengin eriyiklerin, kireçtașlarındaki karbonat çözülmesi sırasında (Șekil 14) kireçtașlarını metazomatize ederek çökelmesiyle olușmuștur. Kireçtașlarındaki $\delta^{13} \mathrm{C}_{\mathrm{PDB}}$ değerlerinin siderit cevherleșmelerindekinden yüksek olması, bölgesel metamorfizma ve Prekambriyen yaşlı Emirgazi Formasyonu içinde oluşan metapelitikbitümlü şeylerin varlığıyla açıklanabilir.

Prekambriyen yașlı bitümlü șeyler ve metapelitik kayaçlar içindeki sedimanter piritler (Fe-sülfidler) ve birincil baritlerden (sülfatlar) de elde edilen izotop değerleri (Küpeli vd., 2007), birincil siderit cevherleșmelerinin olușum koșullarıyla örtüşmektedir. Sedimanter Fe-sulfidler olan piritlerden (Șekil 10D) elde edilen $\delta^{34} S$ değerleri (\%॰22.30-23.00) ile baritlerden elde edilen $\delta^{34} \mathrm{~S}$ (\%॰32.40-38.30 arası) ve $\delta^{18} \mathrm{O}_{\text {vsmow }}$ değerleri (\%॰12.20-14.70 arası) daha geç evre ve süperjen cevherleşmelerle kıyaslandığında, Permiyen-Tersiyer zaman aralığındaki deniz suyunun $\delta^{34} S$ (\%॰10-22 arası) ve $\delta^{18} \mathrm{O}(\% \circ 7-12$ arası) değerlerinden daha yüksektir (Claypool vd.,1980). Bu sülfür ve oksijen izotopik değerler ile birincil kökenli sideritlerden elde edilen $\delta^{18} \mathrm{O}_{\text {vsmow }}$ değerleri (\%o19.80-20.66 arasında), Prekambriyen-Kambriyen zaman aralığındaki deniz suyunun izotop içeriklerine yakınlık göstermektedir (Claypool vd., 1980). Ayrıca sedimanter piritlerdeki bu $\delta^{34} S$ değerleri de Geç Proterozoyik zamanındaki deniz suyu değerlerine de yakınlık göstermektedir. Sedimenter pirit olușumları, değișik çökelme yapısı ve diyajenetik özelikler gösteren organik maddelerle birlikte bulunan, șeyl-fillit türü kayaçlar içerisinde mevcut olup (Ayhan vd., 1992), bunların İnfra-Kambriyen esnasında hüküm süren indirgen ortam șartlarında oluștuklarını göstermektedir.

\section{TARTIȘMA VE DENEȘTIRME}

Jeolojik süreçler boyunca tektonizmanın etkili olduğu Doğu Toroslar'ın batı kesiminde yer alan bölgede Paleosen-Eosen zaman aralığında (Ayhan vd.,1992;
Dayan, 2007; Küpeli, 2010) oluștuğu düșünülen ve șu anda çoğunlukla yan kayacı Orta-Üst Kambriyen yașlı kireçtașları olan ve işletilen (Attepe, Karaçat, Elmadağbeli demir yatakları) geç evre hematit ve süperjen götit-limonit gibi cevherleșmelerin olușum kökeni konusunda tartıșmalar halen devam etmektedir. Bölgede cevherleșmenin yașı ile ilgili șu ana kadar herhangi bir çalıșma yapılmamıștır. Yapılan tüm çalıșmalarda cevher-yan kayaç modellemesi üzerinden gidilmiștir. Arazi gözlemleri, cevher mikroskopisi, SEM analizleri ve izotop çalıșmalarından elde edilen sonuçlara göre Emirgazi Formasyonu içindeki birincil (sinjenetik) sideritler, denizel bir ortamda, sedimanter ve diyajenetik koșulların hakim olduğu, karbonatlı kayaçların çökeldiği Prekambriyen-Kambriyen zaman aralığında çökelmiş ve oluşmuştur. Kretase sonrası dönemde gelișen KD-GB yönlü faylar kanal görevi yaparak, Prekambriyen yașlı Emirgazi Formasyonu içindeki birincil siderit (ve +/-pirit) cevherleșmelerini çözerek Fe elementinin, Kambriyen ve daha genç birimler içerisine tașınmasını sağlayarak hematit yataklarını olușturmușlardır (Keskin, 2016c). Paleosen-Eosen sırasındaki nap hareketleri (Özgül, 1976) ve Miyosen döneminde gelișen fay zonlarında yaygın biçimde gelișen karstlașma ve yüzeysel alterasyon olaylarının etkisinde kalan cevherler oksitlenerek limonit ve götit gibi süperjen cevher minerallerine dönüșmüșlerdir. Miyosen ve sonrası tektonik rejimde gelișen en genç sistemleri olușturan KD-GB ve KB-GD uzanımlı sol ve sağ yanal doğrultu atımlı faylar (cevherleșme sonrası faylar) alandaki tüm kırık sistemlerini ve cevherleșmeleri kesmektedir. Geç Miyosen'den itibaren geliștiği düșünülen bu faylar, doğrultu atım karakterinde olmakla beraber, az da olsa eğim atım bileșenine de sahiptirler.

Prekambriyen yașlı Emirgazi Formasyonu'nun birimleri içinde yer alan primer siderit cevherleșmelerinin ve sedimanter piritlerin bulunduğu ortam ve kayaç litolojisi, Batı Toroslar'da Güvercinoluk Formasyonu (Bozkaya vd., 2006; Gürsu ve Göncüoğlu, 2006), Orta Toroslar'da tanımlanan Kozan Formasyonu (Özgül ve Kozlu, 2002), Sultandağları'nda ve Doğanhisar bölgesinde Gökoluk Formasyonu (Özgül vd., 1991), Amanos Dağları yöresinde Eğribucak Formasyonu (Atan, 1969), Doğu Toroslar'da Tufanbeyli-Kozan bölgesinde yer alan tüf-tüfit ara seviyeli kumtașı, kiltașı, silttașı ve kuvarsitlerden olușan Oruçlu Formasyonu (Özgül ve Kozlu, 2002), Mardin-Derik bölgesinde Prekambriyen yașlı andezit, spilitik andezit, aglomera, kumtașı, silttașı, konglomera ve benzeri kaya birimlerini içeren Telbesmi Formasyonu (Ketin, 1966), diyabaz 
Çizelge 1. Oksijen $\left(\delta^{18} \mathrm{O}\right)$ ve Karbon $\left(\delta^{13} \mathrm{C}\right)$ izotop analiz sonuçları.

Table 1. Results of Oxygen $\left(\delta^{18} \mathrm{O}\right)$ and Carbon $\left(\delta^{13} \mathrm{C}\right)$ isotope analysis.

\begin{tabular}{|c|c|c|c|c|c|c|c|}
\hline Örnek No & Mineral & Olușum & $\begin{array}{l}\delta^{13} \mathrm{C} \% \\
\text { VPDB }\end{array}$ & $\begin{array}{l}\delta^{18} \mathrm{O} \% \\
\text { VPDB }\end{array}$ & $\begin{array}{c}\delta^{18} \mathrm{O} \% \\
\text { VSMOW }\end{array}$ & $\begin{array}{c}\text { C std } \\
\text { dev. }\end{array}$ & $\begin{array}{l}\text { O sto } \\
\text { dev. }\end{array}$ \\
\hline S6/K706 & Siderit & Birincil & -0.77 & -9.95 & 20.65 & 0.022 & 0.014 \\
\hline S7/K706 & Siderit & Birincil & -0.71 & -10.19 & 20.41 & 0.022 & 0.010 \\
\hline S8/K706 & Siderit & Birincil & -1.62 & -9.95 & 20.66 & 0.007 & 0.062 \\
\hline S9/K706 & Siderit & Birincil & -1.07 & -10.60 & 19.98 & 0.032 & 0.032 \\
\hline S11/K706 & Siderit & Birincil & -1.12 & -10.68 & 19.90 & 0.015 & 0.035 \\
\hline S1/K706 & Siderit & İkincil & -6.57 & -10.43 & 20.16 & 0.073 & 0.085 \\
\hline S2/K706 & Siderit & İkincil & -6.62 & -11.20 & 19.37 & 0.007 & 0.042 \\
\hline S3/K706 & Siderit & İkincil & -6.85 & -10.29 & 20.30 & 0.056 & 0.064 \\
\hline S4/K706 & Siderit & İkincil & -7.94 & -12.03 & 18.50 & 0.017 & 0.009 \\
\hline S5/K706 & Siderit & İkincil & -7.09 & -10.96 & 19.61 & 0.020 & 0.044 \\
\hline S10/K706 & Siderit & İkincil & -6.77 & -11.28 & 19.28 & 0.011 & 0.058 \\
\hline
\end{tabular}

$\mathrm{PDB}=($ Pee Dee Belemnite $)$

$\mathrm{V}-\mathrm{SMOW}=($ Vienna-Standart Ortalama Okyanus Suyu)

Std dev.= Standart düzeltme

daykı, șist, fillit, kuvars șist, kloritșist, metakonglomera, metaçört ve benzeri birimlerden olușan Bozburun Formasyonu (Șenel ve Sönmez, 2006) ile benzerlik göstermekte ve deneștirilebilir özelliktedir. Bu deneștirme, Prekambriyen yașlı Emirgazi Formasyonu'nun oluștuğu havza koșulları ve jeotektonik ortamını yansıtma açısından önemlidir. Bu formasyonların oluștuğu kușak boyunca Pan-Afrikan Orojenezi etkin olmuș ve aynı kaynaktan beslenmișlerdir. Özellikle Amanoslar'da mostra veren ve ilk defa bulunan iz fosillerle Prekambriyen yașı verilen (Önalan, 1986), fakat temeli görülemeyen Eğribucak Formasyonu, derin denizel ortamda çökelen grovak, laminalı șeyl türü kayaçlar ile düșük dereceli metamorfik kayaçlar olan metakumtașları ile temsil edilmektedir. Formasyonun gerek litolojisi gerekse de olușum ortamı (Şekil 9 ve 15) çalıșma alanındaki Emirgazi Formasyonu'nun olușum koșulllarıyla benzerlik sunmaktadır. Birincil kökenli düșük manganlı sin-sedimanter siderit cevherlerindekii $\delta^{13} \mathrm{C}$ izotopik değerleri (0'a yakın), cevherleșmelerin bu derin denizel ortam koșullarında oluștuğunu göstermektedir (Șekil 15). Ayrıca Prekambriyen birimler içindeki sedimanter piritlerdeki $\delta^{34} S$ değerleri de Geç Proterozoyik zamanındaki deniz suyu değerlerine yakınlık göstermekte (Claypool vd.,1980) ve bu ortam koșullarında Fe-sülfid cevherleşmelerinin olduğu görülmektedir (Ayhan vd.,1992). Çalıșma alanında baritlerden elde edilen (Küpeli vd., 2007) $\delta^{34} S$ ve $\delta^{18} \mathrm{O}$ izotop verileri de Geç Proterozoyik-Alt Kambriyen zaman aralığında olușan denizel barit yataklarına işaret etmekte (Wang ve Li, 1991) ve primer sideritler gibi (Șekil 15) derin deniz ortamlarında çökeldiğine işaret etmektedir.

Derin denizel ortamda çökelen Prekambriyen yașlı Eğribucak Formasyonu üzerine uyumsuz olarak gelen Alt Kambriyen yașlı Eğrek Formasyonu (Șekil 15A ve B) ise kuvars arenitlerden olușmuș olup Zabuk Formasyonu kayaçlarıyla benzer özelliktedir (Önalan, 1986). Eğrek Formasyonu birimleri yüksek enerjili, sığ bir șelf ortamında çökelmiștir (Dean ve Özgül, 1979) (Şekil 15A). Günümüzde ișletilen geç evre hematit ve süperjen götit cevherleşmelerinin bulunduğu Ort-Üst Kambriyen yaşlı Değirmentaş Formasyonu'nun kireçtaşları ise, düşük enerjili, duraylı bir şelf ortamı koşullarını yansıtan Orta Kambriyen yaşlı Koruk Formasyonu'nun kireçtașlarıyla ile benzer ortam koșullarında olușmuștur (Șekil 15A). Karaya yakın duraylı bir șelf ortamında çökelen bu karbonatlı kayaçların, çökelme koșullarındaki değișikliklerinden dolayı $\delta^{13} \mathrm{C}$ izotop değerlerinde hafif değișimler ve $\delta^{18} \mathrm{O}_{\text {vsmow }}$ değerlerin de zenginleșen oranlar da görülmektedir (Șekil 15).

Attepe ve çevresi demir yataklarında olduğu gibi birincil siderit cevherleșmesinin oluștuğu metalojenik kușak göz önüne alındığında, bu kușak boyunca (İran, Hindistan) çok sayıda Prekambriyen yașı de- 


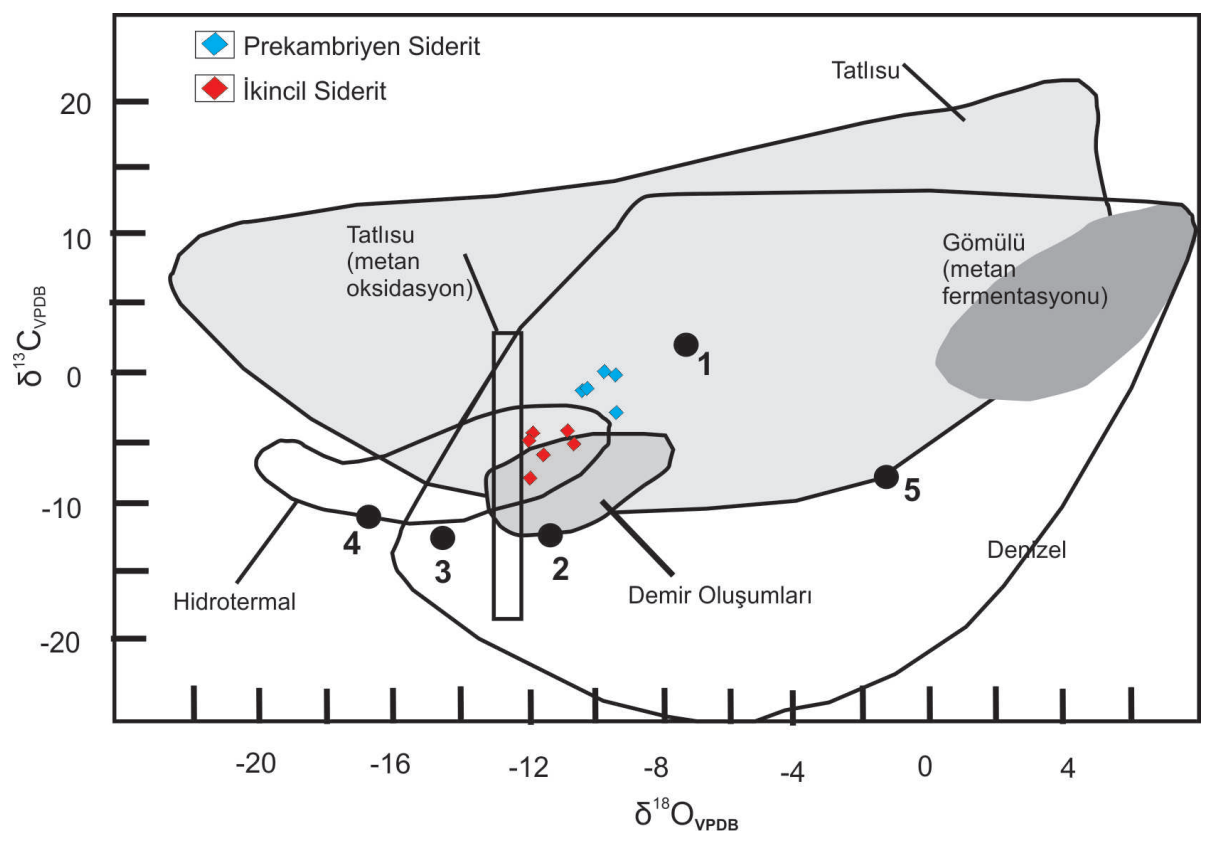

Şekil 13. Sideritlerden elde edilen $\delta^{18} \mathrm{O}$ ve $\delta^{13} \mathrm{C}$ izotop değerlerinin gösterdiği olası çökelme ortamları (Diyagram Damyanov, 2002'den alınmıștır). 1- Düșük-Mn'lı diyajenetik siderit alanı. 2- Mn-Mg'lu siderit. 3- İri taneli özșekilli kristalli Mn-Mg siderit (barit ve sülfitlerle ilișkili). 4- Diyajenetik olarak sideritleșmiș organik kalıntılar. 5- Oolitik Siderit. Bu çalıșmada analiz edilen birincil sideritler, diyajenetik olușumlu düșük Mn içerikli alana düșerken, ikincil sideritler hidrotermal kökenli demir olușumlarına ișaret etmektedir.

Figure 13. Possible depositional enviroments of $\delta^{18} \mathrm{O}$ and the $\delta^{13} \mathrm{C}$ isotope values obtained from siderite (Diagram taken by Damyanov, 2002). 1- Lower-Mn diagenetic of siderite area. 2- Mn-Mg siderite. 3- coarse-grained, idiomorphic Mn-Mg siderite crystalline (associated with barite and sulphides). 4- Diagenetically sideritized organic remnants. 5- Oolithic siderite. While analysised primary siderites plot to low-Mn content area in diagenetical setting, secondary siderites indicate hydrothermal origin of iron formation, in this study.

mir cevherleșmeleri bulunmaktadır (Rajabi vd., 2015). İran'daki demir yatakları Pan-Afrikan Orojenezi ile ilgili yataklar olup bunlar Geç Neoproterozoyik-Alt Kambriyen zaman aralığında gelișen bir dizi kıta içi riftleșme ile ilișkilidir. Arap ve Hindistan plakaları arasındaki Proto-Tetis okyanusunun kenarı boyunca yer alan İran'daki yataklanmalar, alkalen volkanizma ve spilitik bazaltların eșlik ettiği, denizaltı volkanizmasının olduğu yay-gerisi bir havza ortamında gelișmișlerdir. (Rajabi vd., 2012). İran'daki Chahmir ve Koushk'taki SEDEX tipi Zn-Pb yatakları, sin-sedimanter faylarla ilișkili, yarı graben sisteminde olușmușlardır. Bölgedeki Zarigan P-Fe, Chahgaz Fe-P, Esfordi, $\mathrm{P}-\mathrm{Fe}$ ve Narigan Fe-Mn yatakları volkano-sedimanter özellikte yataklar olup yay gerisi havzada meydana gelen bir riftleșme ile ilișkilidirler (Rajabi vd., 2015). Chahmir ve Koushk'taki sin-sedimanter faylar, sübsidans sırasında aktif rol alarak kanal görevi yapıp cevherli hidrotermal sıvıların geçișini sağlamıșlar ve cevherin gelișmesinde etkin olmușlardır. ZariganChahmir havzasındaki bu yataklar anoksik koșullar altında çökelen, meta-sedimanter kayaçların bulunduğu, sin-sedimanter faylara yakın olan SEDEX Zn$\mathrm{Pb}$ depolanmalarıdır. Kousk SEDEX Fe-Mn ve $\mathrm{Zn}-\mathrm{Pb}$ yatakları ise rift kökenli sedimanter bir ortamda, kıta içi tektonik ortamı yansıtan kıtasal magmatik yayla ilișkili asitik-bazik kayaçlarla aynı ortamda olușmușlardır (Yaghubpur ve Mehrabi, 1997). Bölgedeki stratabound tipi demir cevherleșmeleri Esfordi ve Mishdovan bölgesinde yer almakta olup bu yataklar volkano-sedimanter kayaçlar içinde olușmaktadır (Jami vd., 2007). Stratiform demir olușumları ise Esfordi bölgesinde sin-volkanosedimanter kayaçlarla birlikte bulunmakta ve hidrotermal sıvıların doğrudan deniz tabanında çökelmesi ile olușan sedimanter-eksalatif demir yatakları olarak yorumlanmaktadır (Aftabi vd., 2009). Bu tip yatak olușumlarına Almanya'daki Lahn Dill demir yatağı (Dill ve Botz, 1989; Dill 2010) ve Malatya-Deveci siderit yatağı örnek verilebilir (Ünlü, 1983, 1987). Devoniyen-Alt Karbonifer yașlı Lahn-Dill tip demir yatağında siderit-hematit birlikteliği gözükürken, Deveci demir yatağında sadece siderit cev- 


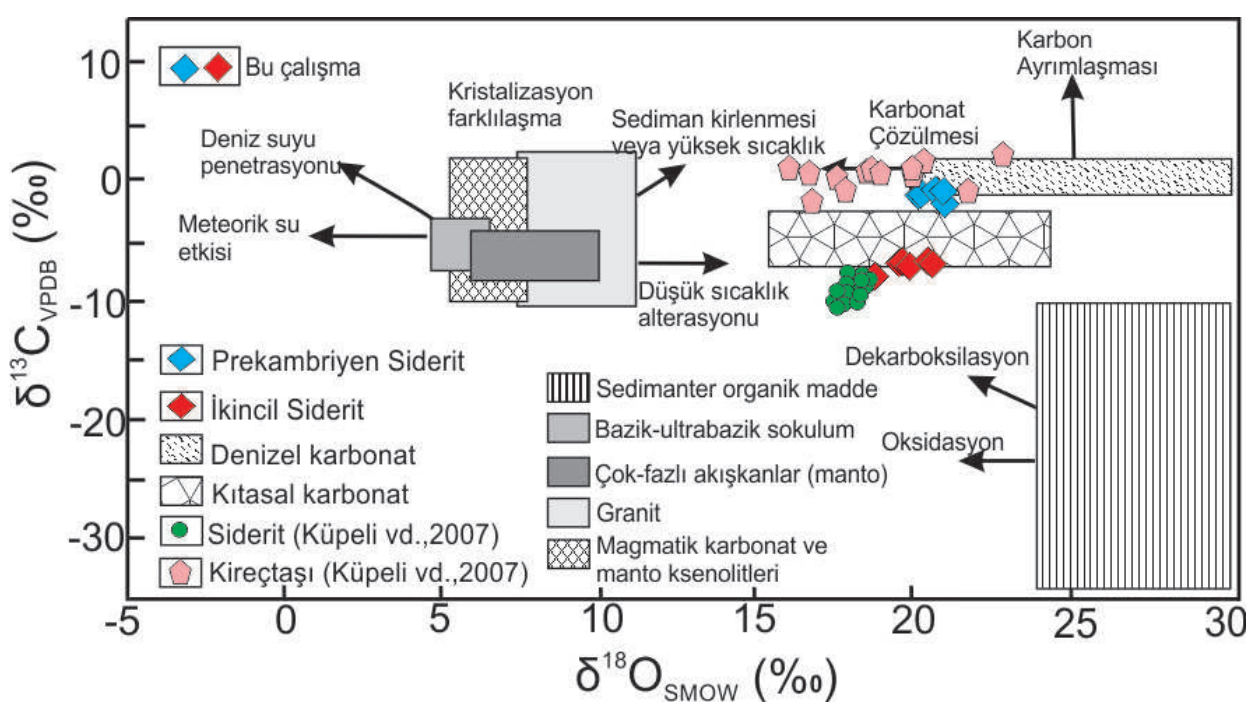

Şekil 14. Siderit örneklerinin $\delta^{13} \mathrm{C}_{\mathrm{PDB}}$ karșı $\delta^{18} \mathrm{O}_{\mathrm{vSmow}}$ grafiği. Veriler denizel karbonat (Baker ve Fallick, 1989; Hoefs,1997), kıtasal karbonat (Hoefs, 1997), sedimanter organik madde karbonu (Hodson, 1977; Hoefs,1997), ve magma-manto karbonatını (Ray vd., 1999) içeren 4 farklı alandan olușmaktadır. Diyagramdaki diğer alanlar Wang vd., 2015’ten alınmıștır. Bu çalıșmada elde edilen sonuçlara göre birincil siderit örnekleri denizel karbonatların olduğu alana düșmektedir. İkincil kökenli siderit cevherleșmelerimiz önceki çalıșmalarda elde edilen verilerle birlikte (Küpeli vd., 2007) kıtasal karbonat alanında sonraki hidrotermalmetazomatik süreçte oluşan siderit cevherleşmeleridir.

Figure 14. $\delta^{13} C_{P D B}$ versus $\delta^{18} O_{V S M O W}$ plots for siderite samples. Data consist of four different areas including marine carbonate (Baker et Fallick, 1989; Hoefs, 1997), continental carbonate (Hoefs, 1997), sedimentary organic matter carbons (Hodson, 1977; Hoefs, 1997), and the magma mantle carbonate (Ray et al., 1999). Other areas in the diagram taken by Wang et al. (2015). Primary siderite samples plot the marine carbonate field in this study. Secondary-origin siderite mineralizations and previous data results (Küpeli et al., 2007) plot the continental carbonate field and formed during the hydrothermal-metasomatic process.

heri görülmektedir. Riftleșme ile ilișkili hidrotermal sistemlerin olușturduğu yay-gerisi havzalardaki bu tip yatakların bulunduğu anoksik, stratiform havzalar metalce zengin sedimanların içerdiği demir oksit, silikat, sülfit ve karbonatların çökeldiği havzalardır. Demir ve silikaca zengin bu tür havzalara Batı Afrika'daki Çad Gölü'nün tabanındaki sedimanlarda olușan oolitik demir yataklarının olușumu da örnek gösterilebilir (Lemolle ve Dupont, 1973).

Yukarıdaki havza koșullarıyla benzer özellikler gösteren Geyikdağı Tektonik Birliği içindeki Emirgazi Formasyonu Türkiye'de, KB Gondwana'nın İnfra-Kambriyen yașlı kayaç birimlerini temsil etmekte ve $\mathrm{KB}$ Gondwana'nın en kuzeyinde yer alan kayaç birimleriyle benzer özellik göstermektedir (Șekil 15B). Formasyonun olușumu olasılıkla Geç Prekambriyen-Erken Kambriyen zamanında genișlemeli rejimin etkili olduğu bir zaman dilimine denk gelmekte ve çökelme ortamı riftle ilișkili bir sedimantasyon ortamını yansıtmaktadır (Şekil 15) (Cater ve Turnbridge, 1992; Dean ve Monod, 1997; Kozlu ve Göncüoğlu, 1997; Göncüoğlu ve Koz- lu, 2000; Ghienne vd., 2010). Bu zaman aralığı (İnfraKambriyen- Erken Kambriyen) sırasında Toroslar'da Pan-Afrikan orojenezi bileșimli KB Gondwana perikratonik kenarın yay gerisi genișleme ve/veya açılmasıyla riftleștiği ve çalıșma alanındaki volkanik kayaçların bu rejim sonucu ortaya çıktığı (Gürsu, 2008; Tiringa vd., 2009; Keskin ve Ünlü, 2012; Gürsu vd., 2015) ve bu volkanik kayaçların birincil siderit cevherleșmeleri ile ilișkili olabilecekleri görülmektedir. İnceleme alanında birincil siderit cevherleșmelerinin bulunduğu Emirgazi Formasyonu bu paleotektonik ortamda yer almakta ve cevherleșme Devoniyen-Alt Karbonifer yașlı LahnDill tip demir yatakları gibi (Bottke, 1963; Dill ve Botz, 1989; Dill, 2010) eksalatif sedimanter yatakların (Large, 1981; Lydon, 1996) metamorfizmaya uğramıș eșleniklerine benzerlik göstermektedir.

\section{SONUÇLAR}

Attepe demir yatağında izlenen birincil siderit cevherleșmeleri, Prekambriyen yașlı Emirgazi Formasyonu 


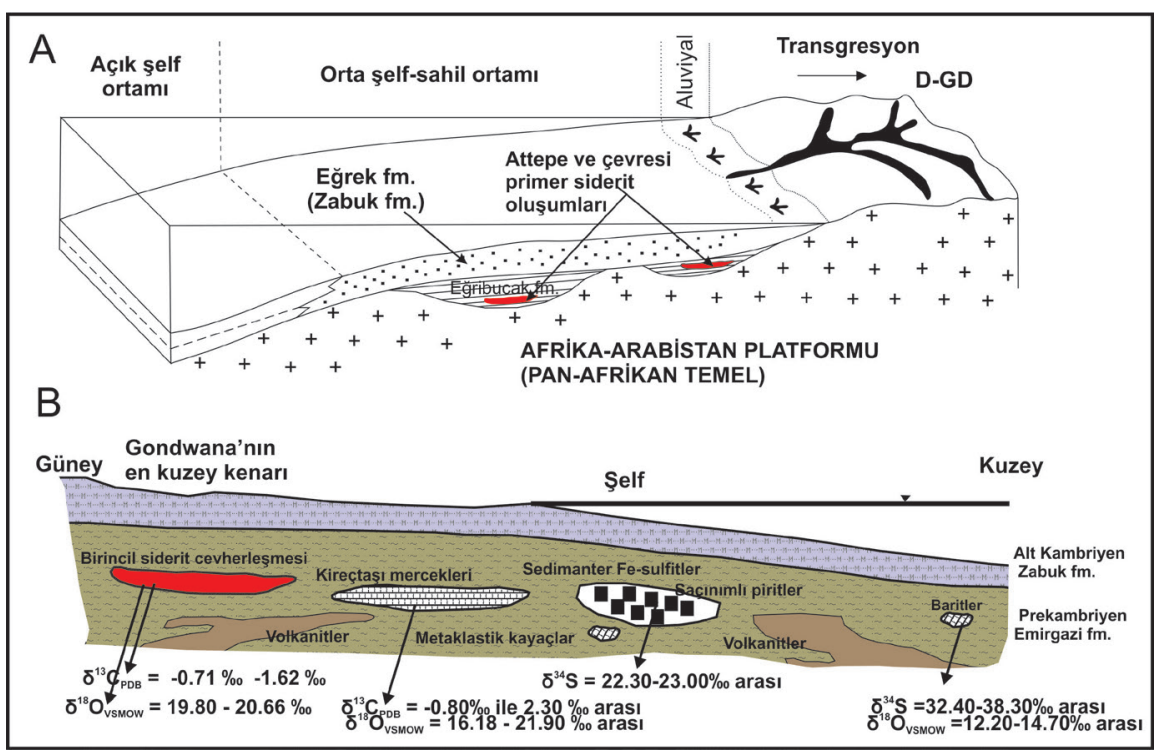

Şekil 15. A) Prekambriyen-Alt Kambriyen zamanında Emirgazi ve Zabuk formasyonlarının çökelme ortamları (Önalan, 1986), B) Prekambriyen-Alt Kambriyen zamanında Gondwana'nın en kuzey kenarındaki çökelme ortamı ve paleo-coğrafik profili ve primer cevherleșmelerin bu formasyonla olan stratigrafik ilișkisi (Șekil 9A'ya bakınız).

Figure 15. A) Depositional settings of Emirgazi and Zabuk formation in Precambrian-Lower Cambrian time (Önalan, 1986). B) Depositional setting and paleo-geographic profile at the northern edge of Gondwana, and stratigraphic relationship of primary siderite mineralizations with these formations in Precambrian-Lower Cambrian time (See Figure 9A).

içerisinde olușmuș, sin-sedimanter/volkano-sedimanter olușum kökenli bir cevherleșmedir. KB Gondwana'nın Prekambriyen yașlı kayaç birimlerini temsil eden Emirgazi Formasyonu içindeki sinjenetik siderit cevherleșmelerinin olușumu Pan-Afrikan Orojenezi ile ilișkili olduğu düșünülmektedir. Cevher mikroskopisi çalıșmalarında birincil olușumlu siderit ve geç evre hematit, götit, siderit ve limonit parajenezi ortaya konulmuștur. Siderit örneklerinden elde edilen $\delta^{13} \mathrm{C}$ ve $\delta^{18} \mathrm{O}$ izotop sonuçlarına göre; birincil kökenli demir cevherleșmeleri, diyajenetik veya sin-sedimanter demir olușumlarını, ikincil kökenli geç evre demir cevherleșmeleri ise demirce zengin hidrotermal-metazomatik kökeni ve Mn-Mg siderit cevherleșmelerini göstermektedir Birincil siderit cevherleșmelerinin derin denizel ortamda, anoksik ortam koșullarında oluștuğunu göstermektedir. Bu dönemde karbonat zenginleșmeleri de siderit olușumlarına eșlik etmektedir.

Geç Kretase'de ve Paleosen-Eosen zaman aralığında bölgede meydana gelen ofiyolit üzerlemesi ve nap hareketlerinden dolayı birçok ters faylar ve kıvrımlamalar gelișmiștir. Bu dönemde KB-GD yönlü sıkıșma kuvvetlerinin etkisi ile olușan ters fay zonlarına sideritlerden çözünme yolu ile olușan hidrotermal hematit-götit cevherleșmeleri yerleșmiștir. Karaçat,
Attepe, Elmadağbeli, Ayıdeliği, Menteș, Mağarabeli ve Kartalkaya geç evre demir yatakları bu dönemde olușmuștur. Orta-Üst Kambriyen yașlı kireçtașları içinde hidrotermal-metazomatik olarak yerleșmiș olan bu hematit ve götit gibi cevherleșmelerin olușumundan sonraki evrelerde karstlașmalarda da etkilidir. Bu cevherleșmelerin dıșında Jura-Kretase yașlı metakonglomeratik seviyeler içerisinde Karakızoluğu demir cevherleșmesi gibi zenginleșmelere de rastlanmaktadır. Fay düzlem kayma verileri ve kıvrım analizlerine göre, çalışma alanında KKB-GGD yönlü sıkıșma ve KKD-GGB yönlü gerilme rejiminin etkin olduğu düșünülmektedir. İnceleme alanındaki sol ve sağ yönlü makaslama zonlarına bağlı olarak gelişen yapılar dikkate alındığında, doğrultu atım tektoniği şu an bölgede baskın olan rejimdir. Bu da bölgede etkin olan Orta Anadolu Fay Zonu (Ecemiş Fayı) ile ilişkilidir. Eosen-Miyosen ve sonraki dönemde gelişen bu KDGB ve KB-GD doğrultu atımlı faylar, tüm fayları ve günümüz ișletilen geç evre hematit, götit gibi cevherleșmeleri kesmektedir.

\section{KATKI BELIRTME}

Bu çalıșma birinci yazarın ikinci yazar danıșmanlığında bitmiș olan doktora tezinin (Ankara Üniversitesi, 
Fen Bilimleri Enstitüsü) bir bölümünü olușturmaktadır. Yazarlar, arazi çalıșmalarındaki yardımlarından dolayı Veysel IȘIK (Ankara Üniversitesi), İsmail AKÇA (MTA) ve Necdet ARDA'ya (MTA), parlatma kesit incelemelerindeki katkıları sebebi ile Şükrü KOÇ’a (Ankara Üniversitesi), SEM çalıșmalarındaki katkılarından dolayı Nihal GÖRMÜȘ'e (MTA) ve de izotop analizlerinin yapılması ve yorumlamasına katkı sağlayan David DETTMAN'a (Arizona Üniversitesi) teșekkür ederler. Bu çalıșma MTA Genel Müdürlüğü'nün 2009-32-1302-1 kodlu Kayseri-Adana Havzası Demir Aramaları Projesi ile kısmen desteklenmiştir.

\section{KAYNAKLAR}

Abia, E.H., Nachit, H., Marignac, C., Ibhi, A. ve Saadi, S.A., 2003. The polymetallic Au-Ag-bearing veins of Bou Madine (Jbel Ougnat, eastern Anti-Atlas, Morocco) tectonic control and evolution of a Neoproterozoic epithermal deposit. Journal of African Earth Sciences, 36, 251-271.

Aftabi, A., Mohseni, S., Babeki, A. ve Azaraien, H. 2009. Fluid inclusion and stable isotope study of the esfordi apatite-magnetite deposit - A discussion. Econ. Geol. 104, 137-143.

Akbayram, K., Okay, A. ve Satır, M. 2013. Early Cretaceous closure of the Intra-Pontide Ocean in western Pontides (northwestern Turkey). Journal of Geodynamics, 65, 28-55.

Akça, i., 2011. Yahyalı (Kayseri) Mansurlu-Feke (Adana) Demir Aramaları. MTA Rapor No:11411, Ankara.

Akın, U. ve Çiftçi, Y., 2011. Türkiye'nin Yapısal Süreksizlikleri: Jeolojik-Jeofizik (Gravite ve Manyetik) Analiz. MTA Monografi serisi No:6, Ankara

Andrew, T. ve Robertson, A. H. F. 2002. The Beyșehir-Hoyran-Hadim Nappes: genesis and emplacement of Mesozoic marginal and oceanic units of the northern Neotethys in southern Turkey. Journal of the Geological Society, London, 159, 529-543.

Arda, N., Tiringa, D., Ateșçi, B., Akça, A. ve Tufan, E., 2008. Yahyalı (Kayseri)- Mansurlu (FekeAdana) Yöresi Demir Sahaları Maden Jeolojisi Arama Raporu. MTA Derleme No:11093. Ankara.
Arda, N., Tiringa, D., Çelik, Y., Ateșçi, B. ve Keskin, S., 2009. Özkoyuncu Demir Madeni Ltd. Ști. ne ait IR: 13601 nolu Ruhsat Sahasında Yapılan (Yahyalı-Kayseri) Ücretli Detay Maden Etüt Raporu. MTA Derleme No:11118. Ankara.

Arıkan, Y., 1968. Mansurlu (Feke-Yahyalı) demir zuhurları. MTA Derleme No:3992.

Atan, O., 1969. Eğribucak-Karacaören (Hassa)Ceyhanlı Dazevleri (Kırıkhan) arasındaki Amanos dağlarının jeolojisi. MTA yayınları, No. 139.

Ayhan, A., Küpeli., Ș. ve Amstutz, G.C., 1992. Attepe (Feke-Adana) Demir Yatağının Bitișindeki Pirit Olușumları. MTA Dergisi 114, 85-94.

Baker, A. J. ve Fallick, A. E., 1989. Evidence from Lewisian limestones for isotopically heavy carbon in two-thousand-million-year-old sea water. Nature 337, 352-354.

Bedi, Y. ve Usta, D., 2006. Tufanbeyli-Feke-Kozan Dolayının Paleozoyik Stratigrafisi (Doğu Toroslar), Toros Kușağı ve Güneydoğu Anadolu bölgesi Prekambriyen- Paleozoyik Kaya Birimlerinin Litostratigrafi Adlamaları. Stratigrafi Komitesi 6.Çalıștayı Özler Kitabı, 2223., Ankara.

Bolhar, R., Van Kranendonk., M.J. ve Kamber, BS., 2005. A trace element study of siderite-jasper banded iron formation in the 3.45 Ga Warrawoona Group, Pilbara Craton - Formation from hydrothermal fluids and shallow seawater. Precambrian Research, 137 1-2: 93-114.

Bottke, H., 1963. Zur Kenntnis der dichten Roteisenerze aus Eisenerzlagerstatten des LahnDill-Typs und deren Bildungsbedingungen. Erzmetall, B. 16, 437-494.

Bozkaya, H., Gürsu, S. ve Göncüoğlu, M.C., 2006. Mineralogical evidence for Cadomian tectonothermal event in the western Central Taurides (sandıklı-Afyon area), Turkey. Gondwana Research, 10, 301-315.

Bozkurt, E., 2001. Neotectonics of Turkey - a synthesis. Geodynamica Acta, Volume 14, Issue 1-3.

Brown, M.C., Oliver, N.H.S. ve Dickens, G.R. 2004. The characterization and paragenesis of veining and fluid flow in the Mt. Whaleback iron ore district, eastern Hamersley Province, Western Australia. Precambrian Research, 128, 441-474. 
Brunn, J.H., Dumont, J.F., De Graciansky, P.C., Gutnic, M., Juteau, T., Marcoux, J., ve Poisson, A., 1971, Outline of the geology of the Western Taurides In Geology and History of Turkey. (ed A.S. Campwell), Petroleum Exploration Society of Libya, Tripoli, 225-257.

Burke, K. ve Șengör, A.M.C., 1986. Tectonic escape in the evolution of the continental crust. Geodyn. Ser. 14, 41-53.

Cater, J.M. ve Tunbridge, I.P., 1992. Paleozoic tectonic history of the SE Turkey. Journal of Petroleum Geology 15, 35-50.

Claypool, G.E., Holser, W.T., Kaplan, I.R., Hitoshi,S. ve Zak, I.,1980. The age curves of sulfur and oxygen isotopes in marine sulfate and their mutual interpretation. Volume 28, 199 260.

Cocks, L.R.M., 2000. The Early Paleozoic geography of Europe. Journal Geological Society, 157, 1-10, London.

Dağlıŏlu, C., 1990. Mansurlu yöresi TDÇi sahaları. MTA Derleme No:8910.

Dağlıoğlu, C. ve Bahçeci, A., 1999., Özkoyuncu'ya ait Koruyeri (Mağarabeli) demir madeni Jeoloji Raporu. MTA Maden Etüt Arșiv No: 2913.

Dağlıoğlu, C. ve Arda, N., 2000. Koruyeri (Mağarabeli) ile Kovalı ve Mustafabeyli (TDÇi Genel Müdürlüğüne ait) demir sahalarının Jeoloji Raporu. MTA Maden Etüt Arșiv No: 2891.

Damyanov, Z., 2002. (http://www.clmc.bas.bg/Annreps/Annrep08/annrep8.htm). Annual Report No:8/2002.(Erișim tarihi: 25.03.2016)

David, V. 2008. Structural-geological setting of the Elura-Zn-Pb-Ag massive sulphide deposit, Australia. Ore Geology Reviews, 34, 428-444.

Dayan, S., 2007. Adana-Mansurlu Attepe civarındaki demir yataklarının jeolojik, petrografik ve yapısal özelliklerinin incelenmesi. A.Ü. Fen Bilimleri Enstitüsü, Yüksek Lisans Tezi, 137 sf. (Türkçe).

Dayan, S., Ünlü, T. ve Sayılı, İ.S. 2008. Adana- Mansurlu Attepe Demir Yatağı'nın Maden Jeolojisi. Jeoloji Mühendisliği Dergisi, 32 (2); 1-44.

Dean, W.T. ve Özgül, N., 1979. Orta Toroslar'da Çaltepe Formasyonumun Bağbașı (HadimKonya) yöresindeki yüzeylemesinde bulunan Orta Kambriyen trilobitleri. M T A Dergisi 92, 1-7.
Dean, W.T. ve Monod, O.,1997. Cambrian development of the Gondwanaland Margin in southeastern Turkey. In: Goncuoglu, M.C. and Derman, A.S. (Eds.), Early Paleozoic evolution of NW Gondwana, Turkish Assoc. Petrol. Geol., Sp. Publ. NO. 3, pp. 61-74.

Demirel, I. H. ve Kozlu, H., 1997. Evaluation of burial history, thermal maturity and source rock assessment of the Upper Paleozoic succession of the eastern Taurus region, southern Turkey. Marine and Petroleum Geology, 14 (7-8), 867- 877.

Dewey, J.F., Pitman, W.C., Ryan, W.B.F. ve Bonnin, J., 1973. Plate tectonics and the Evaluation of the Alpine Systems. Geological Society of American Bulletin, 84, 3137-3180.

Dewey, J.F. ve Șengör, A.M.C., 1979. Aegean and surrounding regions complex multiplate and continuum tectonics in a convergent zone. Geol. Soc. Am. Bül., 90, 84-92.

Dewey, J.F., Hempton, M.R., Kidd, W.S.E., Șaroğlu, F. ve Șengör, A.M.C., 1986. Shortening of continental lithosphere: the neotec- tonics of Eastern Anatolia -a young collision zone. Geol. Soc. London, Spec. Publ. 19, 3-36.

Dill, H.G. ve Botz, R., 1989. Lithofacies variation and unconformities in the metalliferous rocks underlying the Permian Kupferschiefer of the Stockheim Basin/F.R. of Germany. Economic Geology, 84: 1028-1046.

Dill, H.G., 2010. The "chessboard" classification scheme of mineral deposits: Mineralogy and geology from aluminum to zirconium. Earth Science Reviews, 100: 1-420.

Eken, E., 2012. Mağarabeli (Mansurlu-Feke Havzası, Adana) Demir Yatağının Maden Jeolojisi. Ankara Üniversitesi Fen Bilimleri Enstitüsü Yüksek Lisans Tezi, 81 s., Ankara (yayınlanmamıș).

El-ghali, M.A.K., Tajorib, K.G., Mansurbega, H., Oglec, N. ve Kalinc, R.M., 2006. Origin and timing of siderite cementation in Upper Ordovician glaciogenic sandstones from the Murzuq basin, SW Libya. Marine and Petroleum Geology 23, 459- 471.

Faure, G.,1986. Principles of Isotope Geology. Wiley, New York, 589 pp.

Fernandez-Nieto, C., J. Torres-Ruiz, J., I. Subías Pérez, I., Fanlo González, I. ve González 
López, J. M., 2003. Genesis of Mg-Fe Carbonates from the Sierra Menera MagnesiteSiderite Deposits, Northeast Spain: Evidence from Fluid Inclusions, Trace Elements, Rare Earth Elements, and Stable Isotope Data. Economic Geology 98(7),1413-1426.

Ghebreab, W., Greiling, R.O. ve Solomon, S. 2009. Structural setting of Neoproterozoic mineralization, Asmara district, Eritrea. Journal of African Earth Sciences, 55, 219-235.

Ghienne, J.-F., Monod, O., Kozlu, H. ve W.T. Dean, W.T. 2010. Cambrian-Ordovician depositional sequences in the Middle East: A perspective from Turkey. Earth-Science Reviews 101 (2010) 101-146.

Gilg, H.A., Struck, U., Vennemann, T. ve Boni, M. 2003, Phosphoric acid fractionation factors for smithsonite and cerussite between 25 and $72^{\circ} \mathrm{C}$. Geochimica et Cosmochimica Acta, v. 67, pp. 4049-4055.

Göncüoğlu, M.C., 1997. Distribution of Lower Paleozoic rocks in the Alpine terranes of Turkey: Paleogeogegraphic constraints. Göncüoğlu, M.C. ve Derman, A. S. (ed). Early Paleozoic In NW Gondwana. Turkish Association of Petroleum Geologist Special Publication, 3, 13-23.

Göncüoğlu, M.C. ve Kozlu, H., 2000. Early Paleozoic evolution of the NW Gondwanaland, data from southern Turkey and surrounding regions. Gondwana Research, 3, 315-323.

Gürsu, S. ve Göncüoğlu, M.C., 2005. Early Cambrian back-arc volcanism in the Western Taurides, Turkey: implications for the rifting along northern Gondwanan margin. Geological Magazine 142 (5), 617-631.

Gürsu, S. ve Göncüoğlu, M.C., 2006. Petrogenesis and tectonic setting of Late Pan-African meta-felsic rocks in Sandıklı area (Western Turkey). International Journal of Earth Sciences 95, 741-775.

Gürsu, S., 2008. Petrogenetic and Tectonic Significance of rift-Related Pre-Early Cambrian Mafic Dikes, Central Taurides, Turkey. International Geology Review. Vol. 50., 895-913.

Gürsu, S., Möller, A., Göncüoglu, M.C., Köksal, S., Demircan, H., Köksal, F.T., Kozlu, H. ve Gürsel, S., 2015. Neoproterozoic continental arc volcanism at the northern edge of the
Arabian Plate, SE Turkey. Precambrian Research, Vol. 258., 208-233.

Gürsu, S., 2016. A New Petrogenetic Model for Metagranitic Rocks in the Central and Southern Menderes Massif - W Turkey: Implications for Cadomian Crustal Evolution within the Pan-African Mega-cycle. Precambrian Research, Vol. 275., 450-470.

Hangari, K.M., Ahmad., S.N. ve Jr. Perry, E.C.,1980. Carbon and Oxygen Isotope Ratios in Diagenetic Siderite and Magnetite from Upper Devonian Ironstone, Wadi Shatti District, Libya. Economic Geology 98(7),1413-1426.

Hemi, J.D., 1985. Study and interpretation of the chemical characteristics of natural waters. US Geological Survey Water Supply Paper No. 2254, 263pp.

Henden, I.., Önder, E. ve Yurt, M. Z., 1978; AdanaKayseri-Mansurlu-Karaköy-Attepe-Elmadağbeli-Kızılmevkii-Menteșdere-Uyuzpınarı demir madenleri Jeoloji ve Rezerv Raporu. MTA Derleme No: 6394 (yayınlanmamıș).

Hodson, J.D.,1977. Stable Isotopes and limestone lithification. J. Geol. Soc.133, 637-660.

Hoefs, J.,1997. Stable Isotope Geochemistry. Springer, Heidelberg. 1-214 pp.

Huggett, J., Dennis,P. ve Gale, A.S., 2000. Geochemistry of Early Siderite Cements from the Eocene Succession of Whitecliff Bay, Hampshire Basin, U.K.Journal of Sedimentary Research 70(5), 1107-1117.

Jami, M., Dunlop, A.C. and Cohen, D.R. 2007. Fluid inclusion and stable isotope study of the Esfordi apatite-magnetite deposit, Central Iran. Econ. Geol. 102, 1111-1128.

Keskin, S., Ünlü, T. ve Arda, N., 2010a. Attepe ve Çevresindeki Demir Yataklarının Yapısal Özellikleri ve Tektoniği, Kayseri-Adana Havzası (Türkiye), 63. Türkiye Jeoloji Kurultayı Bildiri Özleri, 5-9 Nisan 2010, Ankara. MTA Kültür Sitesi, 356.sf.

Keskin, S., Ünlü, T. ve Coșkun, E., 2010b. Elmadağbeli, Menteș, Kartalkaya ve Mağarabeli Demir Yataklarında Jeotermometrik Çalıșmalar (Kayseri-Adana Havzası, Türkiye).IV Ulusal JeokimyaSempozyumu, 26-28 Mayıs 2010, Elazığ., 137. sf.

Keskin, S. ve Ünlü, T., 2012. Geotectonic setting and structural controls of Elmadağbeli, Menteș, 
Karaçat, Kartalkaya and Attepe iron deposits (Kayseri-Adana Region, Turkey). IESCA (International Earth Science Colloquium on the Aegean Region), IESCA-2012, Abstracts, pp 150, İzmir.

Keskin, S. ve Ünlü, T. 2016a. Attepe ve Civarındaki Demir Yataklarında Duraylı İzotop ÇaIșmaları (Kayseri-Adana Bölgesi, Türkiye). 69.Türkiye Jeoloji Kurultayı 11-15 Nisan, MTA Kültür Sitesi, Bildiri Özleri Kitabı, 158159 s., Ankara.

Keskin, S. ve Ünlü, T. 2016b. Attepe Bölgesindeki Prekambriyen Yașlı Demir Yataklarının Oksijen ve Karbon İzotop Jeokimyası (Kayseri-Adana Havzası, Türkiye). Uluslararası VII. Jeokimya Sempozyumu, 16-18 Mayıs, Bildiri Özleri Kitabı, 89-90 s., Antalya.

Keskin, S., 2016c. Attepe Demir Yatağı (Mansurlu Havzası, Adana) ve Çevresi Demir Yatakları ve Zuhurlarının Jeolojisi, Yapısal Özellikleri ve Tektoniği . Ankara Üniversitesi Fen Bilimleri Enstitüsü Doktora Tezi, 218 s., Ankara (yayınlanmamıș).

Ketin, İ., 1966. Güneydoğu Anadolu’nun Kambriyen teşekkülleri ve bunların doğu İran Kambriyeni ile mukayesesi. MTA Dergisi., sayı 66.

Kholodov, V.N. ve Butuzova, G.Y., 2004. Problems of Siderite Formation and Iron Ore Epochs: Communication 2. General Issues of the Precambrian and Phanerozoic Ore Accumulation. Lithology and Mineral Resources, Vol. 39, No. 6, 2004, pp. 489-508.

Koç, A. ve Kaymakcı, N., 2013. Kinematics of Sürgü Fault Zone (Malatya, Turkey): A remote sensing study. Journal of Geodynamics 65 (2013) 292- 307.

Koçyiğit, A. ve Bayhan, A., 1998. A new intracontinental transcurrent structure: the Central Anatolian Fault Zone, Turkey. Tectonophysics 284, 317-336.

Koçyiğit A. ve Deveci, Ș., 2007. A N-S-trending Active Extensional Structure, the Șuhut (Afyon) Graben: Commencement Age of the Extensional Neotectonic Period in the Isparta Angle, SW Turkey. Turkish J. Earth Sci., Vol. 16, 391-416.

Kozlu, H. ve Goncuoğlu, M.C. ,1997. Stratigraphy of the Infra- Cambrian rock-units in the Eastern Taurides and their correlation with similar units in southern Anatolia. In: Goncuoglu, M.C. and Derman, A.S. (Eds.), Early Paleozoic evolution of NW Gondwana, Turkish Assoc. Petrol. Geol., Sp. Publ. NO. 3, pp. 50-60.

Kröner, A. and Stern, R. J. 2005. Pan-African Orogeny. Elsevier Encyclopedia Geology, Volume I, 1-12.

Küpeli, Ș., 1986. Attepe (Mansurlu-Feke) yöresinin demir yatakları. S.Ü. Fen Bil. Ens., Yüksek Lisans Tezi, 111s., Konya (yayınlanmamıș).

Küpeli, Ș., 1991. Attepe (Mansurlu-Feke) yöresi demir yataklarının jeolojik, petrografik ve jenetik incelemesi. S.Ü. Fen Bil. Ens., Doktora Tezi, Konya, 227s.

Küpeli, Ș., Karadağ, M. M., Ayhan, A., Döyen, A. ve Arık, F., 2007. C, O, S and Sr isotope studies on the genesis of Fe-carbonate and barite mineralizations in the Attepe iron district (Adana, Southern Turkey). Chemie der Erde, 67, 313-322.

Küpeli, Ș., 2010. Trace and rare-earth element behaviors during alteration and mineralization in the Attepe iron deposits (Feke-Adana, southern Turkey). Journal of Geochemical Exploration,V.105, 51-74.

Large, D.E.,1981. Sediment-hosted Submarine Exhalative Sulphide Deposits - a Review of their Geological Characteristics and Genesis. in Handbook of Stratabound and Stratiform Ore Deposits; Wolfe, K.E., Editor, Geological Association of Canada, Volume 9, pages 459-507.

Lemoalle, J. ve Dupont, B. 1973. Iron-bearing oolites and the present conditions of iron sedimentation in Lake Chad (Africa). International Union of Geological Sciences, Series A, no. 3, p. 167-178.

Lydon, J.W., 1996. Sedimentary Exhalative Sulphides (SEDEX). in Geology of Canadian Mineral Deposit Types, Eckstrand, O.R., Sinclair, W.D. and Thorpe, R.I., Editors, Geological Survey of Canada, Geology of Canada, no. 8, 130-152.

McClusky, S., Balassanian, S., Barka, A., Demir, C., Ergintav, S., Georgiev, I., Gurkan, O., Hamburger, M., Hurst, K., Kahle, H., Kastens, K., Kekelidze, G., King, R., Kotzev, V., Lenk, O., Mahmoud, S., Mishin, A., Nadariya, M., Ou- 
zounis, A., Paradissis, D., Peter, Y., Prilepin, M., Reilinger, R., Sanli, I., Seeger, H., Tealeb, A., Toksöz, M.N. ve Veis, G. 2000. Global positioning system constraints on plate kinematics and dynamics in the eastern Mediterranean and Caucasus. Journal of Geophysical Research, 105(B3): 5695-5719.

McKenzie, D.P., 1972. Active tectonics of the Mediterranean Region. Geophysical Journal of the Royal Astronomical Society, 30, 109185.

Mackintosh, P.W. ve Robertson, A.H.F., 2009. Structural and sedimentary evidence from the northern margin of the Tauride platform in south central Turkey used to test alternative models of Tethys during Early Mesozoic time. Tectonophysics 473, 149-172.

McLellan, J.G., Oliver, N.H.S. ve Schaubs, P.M., 2004. Fluid flow in extensional environments; numerical modelling with an application to Hamersley iron ores. Journal of Structural Geology, 26, 1157-1171.

Metin, S., Ayhan, A. ve Papak, I., 1986. Doğu Torosların batı kesiminin jeolojisi. MTA Dergisi, 107, $1-13$.

Miller, J.M. ve Wilson, C.J.L., 2004a. Structural analysis of faults related to a heterogeneous stress history: reconstruction of a dismembered gold deposit, Stawell, western Lachlan Fold Belt, Australia. Journal of Structural Geology, 26, 1231-1256.

Miller, J.M. ve Wilson, C.J.L., 2004b. Stress Controls on Intrusion-Related Gold Lodes: Wonga Gold Mine, Stawell, western Lachlan Fold Belt, Southeastern Australia. Economic Geology, 99, 941-963.

Morad, S., Ben Ismail, H.N., De Ros, L.F., AL-Aasm, I.S. ve Serrihini, N.-E., 1994. Diagenesis and formation water chemistry of Triassic reservoir sandstones from southern Tunisia. Sedimentology 41, 1253-127.

Morad, S.,1998. Carbonate Cementation in Sandstones: Distribution Patterns and Geochemical Evolution. 26. International Association of Sedimentologists 1-26.

Önalan, M., 1986. Amanos dağlarındaki Alt Paleozoyik çökellerinin çökelme ortamları ve bölgenin paleocoğrafik evrimi. TJK Bült., 29, 4963.
Özgül, N., 1971. Orta Torosların Kuzey kesiminin yapısal gelișiminde blok hareketlerinin önemi. TJK Bült. 14 (1), 85-101.

Özgül, N., Metin, S., Göğer, E., Bingöl, İ. ve Baydar, O. 1973. Tufanbeyli dolayının (Doğu Toroslar, Adana) Kambriyen-Tersiyer kayaları. TJK Bül., cilt XVI, sayı 1.

Özgül, N., 1976. Torosların bazı temel jeolojik özellikleri. T.J.K. Bül., 19, 65-78.

Özgül, N., 1984. Stratigraphy and tectonic evolution of the Central Taurides. In: Tekeli, O. ve Göncüoğlu, M.C. (eds). Int. Symposium on the Geology of the Taurus Belt, 77-90.

Özgül, N., Bölükbaşı, S., Alkan, H. ve Öztaş, Y. 1991. Sultan Dağları-Sandıklı-Hama Akdağ Yöresinin Jeolojisi. TPAO Rapor No:3028, Ankara.

Özgül, N. ve Kozlu, H., 2002. Kozan-Feke (Doğu Toroslar) yöresinin stratigrafisi ve yapısal konumu ile ilgili bulgular. TPJD Bülteni, Cilt 14, Sayı 1, Sayfa 1-36.

Pye, K., Dickson, J.A.D., Schiavon, N., Coleman, M.L. ve Cox, M., 1990. Formation of siderite-Mgcalcite-iron sulphide concretions in an intertidal marsh and sandflat sediments, North Norfolk, England. Sedimentology 37, 325-343.

Rajabi, A., Rastad, E.,Alfonso, P. ve Canet, C. 2012. Geology, ore facies and sulfur isotopes of the Koushk vent-proximal sedimentaryexhalative deposit, Posht-e-Badam block, Central Iran. Int. Geol. Rev. 54, 1635-1648.

Rajabi, A., Canet, C., Rastad, E. ve Alfonso, P. 2015. Basin evolution and stratigraphic correlation of sedimentary-exhalative $\mathrm{Zn}-\mathrm{Pb}$ deposits of the Early Cambrian Zarigan-Chahmir Basin, Central Iran. Ore Geology Reviews, Vol. 64, 328-353.

Ray, J.S., Ramesh, R. ve Pande, K., 1999. Carbon isotopes in Kerguelen plume-derived carbonatites: evidence for recycled inorganic carbon. Earth and Planetary Science Letters, Vol.170(3), 15, 205-214.

Robertson, A.H.F., Parlak, O. ve Ustaömer, T., 2009. Melange genesis and ophiolite emplacement related to subduction of the northern margin of the Tauride - Anatolide continent, central and western Turkey. Geological Society, London, Special Publications 2009, v.311; p9-66. 
Stern, R.J., 1994. Arc assembly and continental collision in the Neoproterozoic East African Orogen: implications for the consolidation of Gondwanaland. Annual Reviews Earth Planetary Sciences 22: 319-351.

Şenel, M., Usta D., Metin Y., Bedi Y., Vergili Ö., Usta M., Balcı V., Kuru K., Tok T., Özkan, M., K. ve Kop A., 2004. Kozan-Tufanbeyli (Adana) arasındaki yapısal birimlerin jeolojik özellikleri. 57. Türkiye Jeoloji Kurultayı, Bildiri özleri, s. 275.

Şenel, M. ve Sönmez, İ., 2006. Toros Kușağı ve Güneydoğu Anadolu Bölgesi'ndeki Alt Kambriyen Kuvarsitleri (Zabuk Fm.) Öncesine Ait Kaya Birimleri. Stratigrafi Komitesi, 6.Çalıștayı, Özler 9-11sf., Ankara.

Şengör, A.M.C., Satir, M. ve Akkok, R., 1984. Timing of tectonic events in the Menderes Massif, western Turkey: implicationsfor tectonic evolution and evidence for Pan-African basement in Turkey. Tectonics, v. 3, pp. 693707.

Şengör, A.M.C. ve Yılmaz, Y., 1981. Tethyan evolution of Turkey, a plate techtonic approach,. Techtonophysics 75, 81-241.

Tatar, O., Piper, J.D.A., Park, R.G. ve Gürsoy, H., 1995. Palaeomagnetic study of block rotations in the Niksar overlap region of the North Anatolia Fault Zone, Central Turkey.Tectonophysics, 244, 251-266.

Taylor, D., Dalstra, H.J., Harding, A.E., Broadbent, G.C. ve Barley, M.E., 2001. Genesis of highgrade hematite orebodies of the Hamersley Province, Western Australia. Economic Geolology, 96, 837-875.

Taymaz, T., Yilmaz, Y. ve Dilek, Y., 2007. The geodynamics of the Aegean and Anatolia: introduction. Geological Society, London, Special Publication 291,1-16.

Tekeli, O., 1980. Toroslarda, Aladağların Yapısal Evrimi. Türkiye Jeoloji Kurumu Bülteni, 23, 11-14.

Tekeli, O., Aksay, A., Ürgün, B. M. ve Ișık A., 1984. Geology of the Aladağ Mountains. Geology of The Taurus Belt (edd.: Tekeli, O. ve Göncüoğlu, M. C.), 143-158.

Tiringa, D., Ünlü, T. ve Sayılı, İ.S., 2009. Kayseri-Yahyalı-Karaköy, Karaçat Demir Yatağının Maden Jeolojisi . Jeoloji Mühendisliği Dergisi, 33 (1); 1-44.
Tiringa, D. 2016. Karaçat Demir Yatağı (Mansurlu Havzası, Adana) ve Doğusunda Yer Alan Demir Yatakları ve Zuhurlarının Jeolojisi. Ankara Üniversitesi Fen Bilimleri Enstitüsü Doktora Tezi, 283 s., Ankara (yayınlanmamıș).

Tutkun, S. Z., 1984. Saimbeyli (Adana) Yöresinin stratigrafisi. C.Ü. Müh. Fak. Yer Bilimleri Dergisi 1 (1), 31-40.

Ünlü, T. 1983. Die Genese der Siderit-Lagerstatte Deveci in der Hekimhan-Provinz Malatya/ Turkei und ihre wirthschaftliche Bewertung. Doktora Çalıșması, Berlin Teknik Üniversitesi, Almanya, mikrofilm (aynı çalıșma TDÇi Genel Müdürlüğü tarıfndan bastırılmıștır).

Ünlü, T. ve Stendall, H., 1986. Divriği Bölgesi Demir Yataklarının Element Korelasyonu ve Jeokimyası (Orta Anadolu-Türkiye). TMMOB Jeoloji Müh. Odası Dergisi, 28, 5-19, Ankara.

Ünlü, T. 1987. Maden yataklarının değerlendirilmesi yöntemine bir örnek: Deveci Siderit Yatağı (An Example to the Mineral Deposits Evaluation Method: Deveci Siderit Deposit). S. Ü. Müh. Mim. Fak. Derg., Sayı 2, C. 2, 68 -78, Konya.

Wang, Z. ve Li, G.,1991. Barite and Witherite in Lower Cambrian Shales of South China: Stratigraphic Distribution and Chemical Characterization. Economic Geology, 86, 354-363.

Wang, C., Deng, J., Santosh, M., Carranza, E.J.M., Gong, Q., Guo, C. Xia, R. ve Lai, X., 2015. Timing, tectonic implications and genesis of gold mineralization in the Xincheng gold deposit, China: $\mathrm{C}-\mathrm{H}-\mathrm{O}$ isotopes, pyrite $\mathrm{Rb}-\mathrm{Sr}$ and zircon fission track thermochronometry. Ore Geology Reviews, 65, 659-673.

Wilson, T.J., Grunow, A.M. ve Hanson, R.E. 1997. Gondwana assembly: the view from southern Africa and East Gondwana. J. Geodynamics 23, 263-286.

Yaghubpur, A. ve Mehrabi, B. 1997. Koushk zinc-lead deposit a typical black-shale-hosted deposit in Yazd State, Iran. J. Sci. Islam. Repub. Iran 8, 117-125.

Yılmaz, İ. 2004. Mansurlu-Feke Civarının Yapısal Jeolojisi. İstanbul Universitesi, Doktora Tezi, 208 sf (Yayınlanmamıș). 